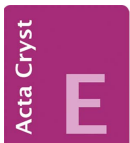

CRYSTALLOGRAPHIC COMMUNICATIONS

ISSN 2056-9890

Received 24 September 2019

Accepted 4 October 2019

Edited by A. J. Lough, University of Toronto, Canada

Keywords: crystal structure; dihydrothiazine; hydrogen bond; $\pi$-stacking; Hirshfeld surface.

CCDC reference: 1957875

Supporting information: this article has supporting information at journals.iucr.org/e

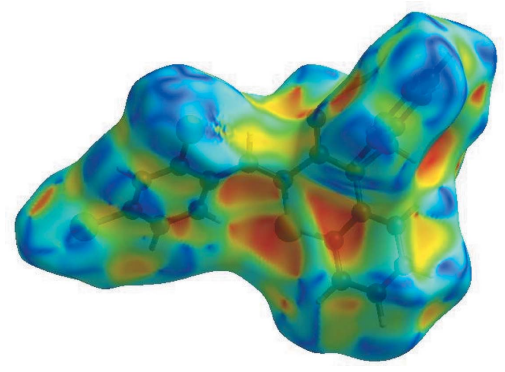

OPEN $\odot$ ACCESS

\section{Crystal structure, Hirshfeld surface analysis and interaction energy and DFT studies of (2Z)-4- benzyl-2-(2,4-dichlorobenzylidene)-2H-1,4-benzo- thiazin-3(4H)-one}

\author{
Nada Kheira Sebbar, ${ }^{\text {a,b }}$ Brahim Hni, ${ }^{\text {b }}$ Tuncer Hökelek, ${ }^{\text {c }}$ Mohamed Labd Taha, ${ }^{\text {a }}$ \\ Joel T. Mague, ${ }^{d}$ Lhoussaine El Ghayati $^{\text {b* }}$ and El Mokhtar Essassi ${ }^{b}$
}

\begin{abstract}
a'Laboratoire de Chimie Appliquée et Environnement, Equipe de Chimie Bioorganique Appliquée, Faculté des Sciences, Université Ibn Zohr, Agadir, Morocco, ${ }^{\mathbf{b}}$ Laboratoire de Chimie Organique Hétérocyclique URAC 21, Pôle de Compétence Pharmacochimie, Av. Ibn Battouta, BP 1014, Faculté des Sciences, Université Mohammed V, Rabat, Morocco, ${ }^{\mathbf{c}}$ Department of Physics, Hacettepe University, 06800 Beytepe, Ankara, Turkey, and ${ }^{\mathbf{d}}$ Department of Chemistry, Tulane University, New Orleans, LA 70118, USA. *Correspondence e-mail: elghayatilhoussaine2018@gmail.com
\end{abstract}

The title compound, $\mathrm{C}_{22} \mathrm{H}_{15} \mathrm{Cl}_{2} \mathrm{NOS}$, contains 1,4-benzothiazine and 2,4-dichlorobenzylidene units, where the dihydrothiazine ring adopts a screw-boat conformation. In the crystal, intermolecular $\mathrm{C}-\mathrm{H}_{\mathrm{Bnz}} \cdots \mathrm{O}_{\mathrm{Thz}}(\mathrm{Bnz}=$ benzene and $\mathrm{Thz}=$ thiazine) hydrogen bonds form corrugated chains extending along the $b$-axis direction which are connected into layers parallel to the $b c$ plane by intermolecular $\mathrm{C}-\mathrm{H}_{\text {Methy }} \cdots \mathrm{S}_{\mathrm{Thz}}$ (Methy $=$ methylene) hydrogen bonds, enclosing $R_{4}^{4}(22)$ ring motifs. Offset $\pi$-stacking interactions between 2,4-dichlorophenyl rings [centroid-centroid $=3.7701(8) \AA$ ] and $\pi$-interactions which are associated by $\mathrm{C}-\mathrm{H}_{\mathrm{Bnz}} \cdots \pi$ (ring) and $\mathrm{C}-\mathrm{H}_{\text {Dchlphy }} \cdots \pi($ ring) (Dchlphy $=2,4-$ dichlorophenyl) interactions may be effective in the stabilization of the crystal structure. The Hirshfeld surface analysis of the crystal structure indicates that the most important contributions for the crystal packing are from $\mathrm{H} \cdots \mathrm{H}$ $(29.1 \%), \mathrm{H} \cdots \mathrm{C} / \mathrm{C} \cdots \mathrm{H}(27.5 \%), \mathrm{H} \cdots \mathrm{Cl} / \mathrm{Cl} \cdots \mathrm{H}(20.6 \%)$ and $\mathrm{O} \cdots \mathrm{H} / \mathrm{H} \cdots \mathrm{O}$ $(7.0 \%)$ interactions. Hydrogen-bonding and van der Waals interactions are the dominant interactions in the crystal packing. Computational chemistry indicates that in the crystal, the $\mathrm{C}-\mathrm{H}_{\mathrm{Bnz}} \cdots \mathrm{O}_{\mathrm{Thz}}$ and $\mathrm{C}-\mathrm{H}_{\mathrm{Methy}} \cdots \mathrm{S}_{\mathrm{Thz}}$ hydrogen-bond energies are 55.0 and $27.1 \mathrm{~kJ} \mathrm{~mol}^{-1}$, respectively. Density functional theory (DFT) optimized structures at the B3LYP/6-311G(d,p) level are compared with the experimentally determined molecular structure in the solid state. The HOMO-LUMO behaviour was elucidated to determine the energy gap.

\section{Chemical context}

1,4-Benzothiazine derivatives constitute an important class of heterocyclic systems. These molecules exhibit a wide range of biological applications, indicating the fact that the 1,4-benzothiazine moiety is a template potentially useful in medicinal chemistry research and therapeutic applications, such as the anti-inflammatory (Trapani et al., 1985; Gowda et al., 2011), antipyretic (Warren \& Knaus, 1987), antimicrobial (Armenise et al., 2012; Rathore \& Kumar, 2006), antiviral (Malagu et al., 1998), anticancer (Gupta et al., 1985; Gupta \& Gupta, 1991) and anti-oxidant (Zia-ur-Rehman et al., 2009) areas. They have also been reported as precursors for the syntheses of new compounds (Sebbar et al., 2015a; Vidal et al., 2006) possessing antidiabetic (Tawada et al., 1990) and anticorrosion activities (Ellouz et al., 2016a,b; Sebbar et al., 2016a). They also possess biological properties (Hni et al., 2019a,b; Sebbar et al., 2017; Ellouz et al., 2017a,b, 2018). As a continuation of our research on the development of $N$-substituted 1,4-benzothiazine deri- 
vatives and the evaluation of their potential pharmacological activities, we report here the synthesis of (2Z)-4-benzyl-2-(2,4dichlorobenzylidene)-2H-1,4-benzothiazin-3(4H)-one, (I), by the reaction of benzyl chloride with $(Z)$-2-(2,4-dichlorobenzylidene)-2H-1,4-benzothiazin-3(4H)-one and potassium carbonate in the presence of tetra- $n$-butylammonium bromide (as catalyst). The molecular and crystal structures, together with the Hirshfeld surface analysis, the intermolecular interaction energies and density functional theory (DFT) computational calculations were carried out at the B3LYP/6$311 \mathrm{G}(\mathrm{d}, \mathrm{p})$ and B3LYP/6-311G(d,p) levels, respectively, for (I) (see Scheme 1).<smiles>O=C1/C(=C/c2ccc(Cl)cc2Cl)Sc2ccccc2N1Cc1ccccc1</smiles>

(l)

Scheme 1

\section{Structural commentary}

The title compound, (I), contains 1,4-benzothiazine and 2,4dichlorobenzylidene units (Fig. 1), where the dihydrothiazine ring, $B$ (atoms $\mathrm{S} 1 / \mathrm{N} 1 / \mathrm{C} 1 / \mathrm{C} 6-\mathrm{C} 8$ ), adopts a screw-boat

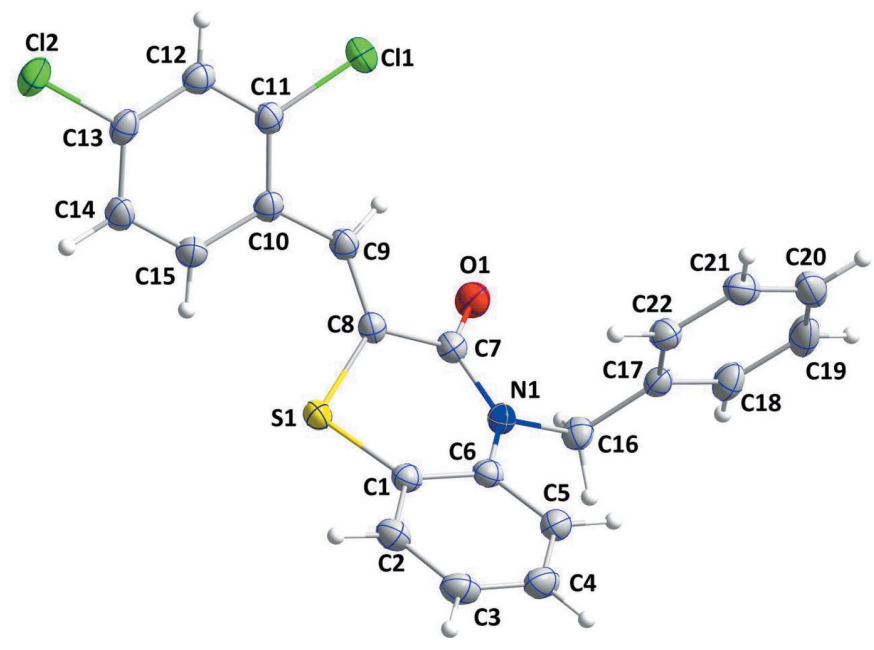

Figure 1

The molecular structure of the title compound with the atom-numbering scheme. Displacement ellipsoids are drawn at the $50 \%$ probability level.
Table 1

Hydrogen-bond geometry $\left(\AA,^{\circ}\right)$.

$C g 1$ and $C g 4$ are the centroids of rings $A(\mathrm{C} 1-\mathrm{C} 6)$ and $D(\mathrm{C} 17-\mathrm{C} 22)$, respectively.

\begin{tabular}{lllll}
\hline$D-\mathrm{H} \cdots A$ & $D-\mathrm{H}$ & $\mathrm{H} \cdots A$ & $D \cdots A$ & $D-\mathrm{H} \cdots A$ \\
\hline $\mathrm{C} 4-\mathrm{H} 4 \cdots \mathrm{O} 1^{\text {ix }}$ & $0.936(19)$ & $2.51(2)$ & $3.3346(17)$ & $147.7(15)$ \\
$\mathrm{C} 16-\mathrm{H} 16 B \cdots \mathrm{S} 1^{\mathrm{v}}$ & $0.945(16)$ & $2.852(16)$ & $3.7011(13)$ & $149.9(12)$ \\
$\mathrm{C} 3-\mathrm{H} 3 \cdots C g 4^{\text {ix }}$ & $0.938(17)$ & $2.901(17)$ & $3.6428(15)$ & $136.8(13)$ \\
$\mathrm{C} 14-\mathrm{H} 14 \cdots C g 4^{\mathrm{x}}$ & $0.971(19)$ & $2.710(18)$ & $3.5593(15)$ & $146.8(14)$ \\
$\mathrm{C} 18-\mathrm{H} 18 \cdots C g 1^{\mathrm{xi}}$ & $0.979(18)$ & $2.969(18)$ & $3.6759(16)$ & $130.0(13)$ \\
\hline
\end{tabular}

Symmetry codes: (v) $x,-y+\frac{1}{2}, z-\frac{1}{2}$; (ix) $-x+1, y-\frac{1}{2},-z+\frac{1}{2}$; (x) $x-1,-y-\frac{1}{2}, z-\frac{1}{2}$; (xi) $x,-y-\frac{1}{2}, z-\frac{3}{2}$.

conformation with puckering parameters (Cremer \& Pople, 1975) of $Q_{\mathrm{T}}=0.4331(10) \AA, \theta=68.34(16)^{\circ}$ and $\varphi=$ 333.95 (17) $^{\circ}$. The planar rings $A(\mathrm{C} 1-\mathrm{C} 6), C(\mathrm{C} 10-\mathrm{C} 15)$ and $D$ (C17-C22) are oriented at dihedral angles of $A / C=60.49(4)^{\circ}$, $A / D=79.69(4)^{\circ}$ and $C / D=41.29(4)^{\circ}$. Atoms $\mathrm{Cl} 1$ and $\mathrm{Cl} 2$ are -0.0156 (3) and 0.0499 (4) $\AA$ from ring $C$ and so are almost coplanar.

\section{Supramolecular features}

In the crystal, intermolecular $\mathrm{C}-\mathrm{H}_{\mathrm{Bnz}} \cdots \mathrm{O}_{\mathrm{Thz}}(\mathrm{Bnz}=$ benzene and $\mathrm{Thz}=$ thiazine) hydrogen bonds form corrugated chains extending along the $b$-axis direction which are connected into layers parallel to the $b c$ plane by intermolecular $\mathrm{C}-$ $\mathrm{H}_{\text {Methy }} \cdots \mathrm{S}_{\text {Thz }}$ (Methy = methylene) hydrogen bonds, enclosing $R_{4}^{4}(22)$ ring motifs (Bernstein et al., 1995) (Table 1 and Fig. 2). Offset $\pi$-stacking interactions between 2,4-dichlorophenyl rings $C$ [atoms $\mathrm{C} 10-\mathrm{C} 15 ; \mathrm{Cg} 3 \cdots \mathrm{Cg} 3^{\mathrm{i}}$, where $\mathrm{Cg} 3$ is the centroid of ring $C$; symmetry code: (i) $-x,-y+1,-z+1$ ], may further stabilize the structure, with a centroid-centroid distance of 3.7701 (8) $\AA$, together with $\pi$-interactions, i.e. $\mathrm{C}-$ $\mathrm{H}_{\mathrm{Bnz}} \cdots \pi$ (ring) and $\mathrm{C}-\mathrm{H}_{\text {Dchlphy }} \cdots \pi($ ring) (Dchlphy $=2,4$-dichlorophenyl). The Hirshfeld surface analysis of the crystal

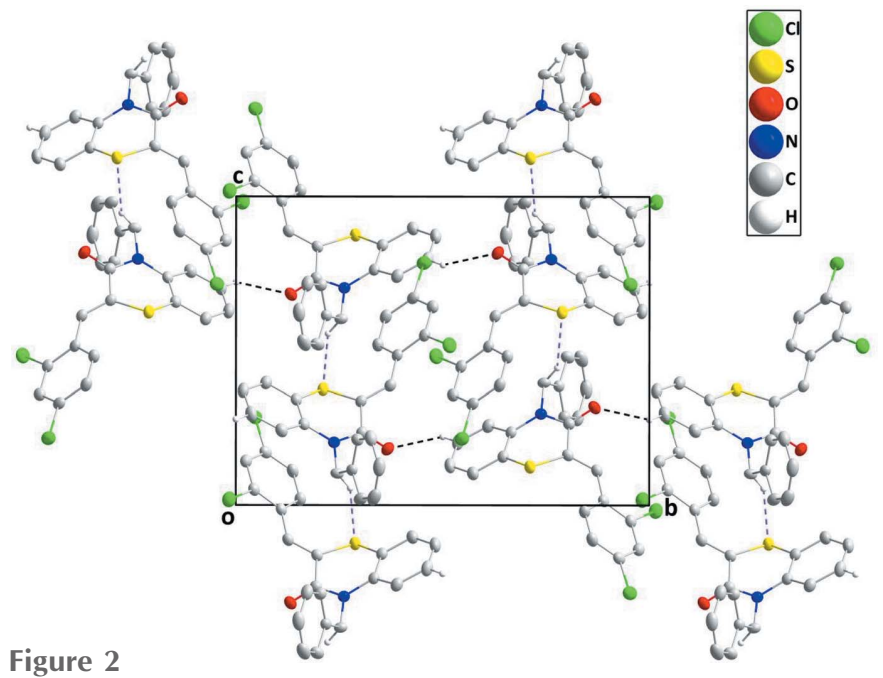

Figure 2

A partial packing diagram, viewed along the $a$-axis direction, with $\mathrm{C}-$ $\mathrm{H}_{\mathrm{Bnz}} \cdots \mathrm{O}_{\mathrm{Thz}}$ and $\mathrm{C}-\mathrm{H}_{\mathrm{Methy}} \cdots \mathrm{S}_{\mathrm{Thz}}(\mathrm{Bnz}=$ benzene, Thz $=$ thiazine and Methy = methylene) hydrogen bonds shown, respectively, as black and light-purple dashed lines. 


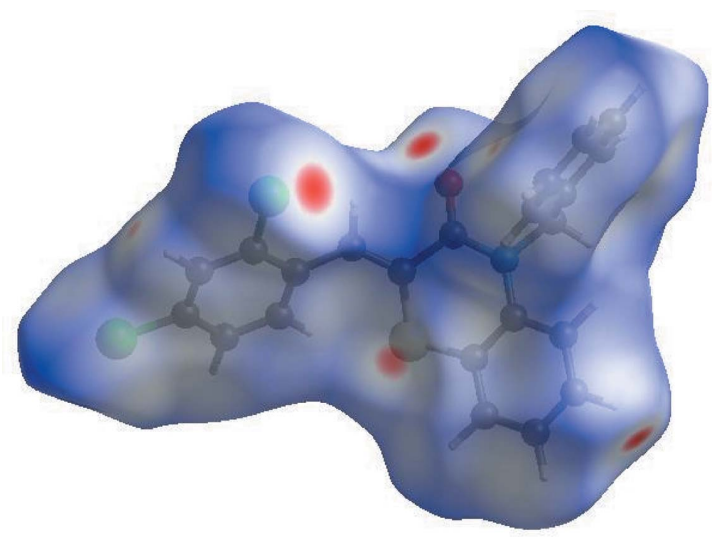

Figure 3

View of the 3D Hirshfeld surface of the title compound, plotted over $d_{\text {norm }}$ in the range -0.1634 to 1.5051 a.u.

structure indicates that the most important contributions for the crystal packing are from $\mathrm{H} \cdots \mathrm{H}(29.1 \%), \mathrm{H} \cdots \mathrm{C} / \mathrm{C} \cdots \mathrm{H}$ $(27.5 \%), \mathrm{H} \cdots \mathrm{Cl} / \mathrm{Cl} \cdots \mathrm{H}(20.6 \%)$ and $\mathrm{O} \cdots \mathrm{H} / \mathrm{H} \cdots \mathrm{O}(7.0 \%)$ interactions. Hydrogen-bonding and van der Waals interactions are the dominant interactions in the crystal packing.

\section{Hirshfeld surface analysis}

In order to visualize the intermolecular interactions in the crystal of (I), a Hirshfeld surface (HS) analysis (Hirshfeld, 1977; Spackman \& Jayatilaka, 2009) was carried out using CrystalExplorer (Version 17.5; Turner et al., 2017). In the HS plotted over $d_{\text {norm }}$ (Fig. 3), the white surface indicates contacts with distances equal to the sum of the van der Waals radii, and the red and blue colours indicate distances shorter (in close contact) or longer (distinct contact) than the van der Waals radii, respectively (Venkatesan et al., 2016). The bright-red spots appearing near atoms $\mathrm{O} 1, \mathrm{~S} 1$ and $\mathrm{H} 4$ indicate their roles

\section{Figure 4}

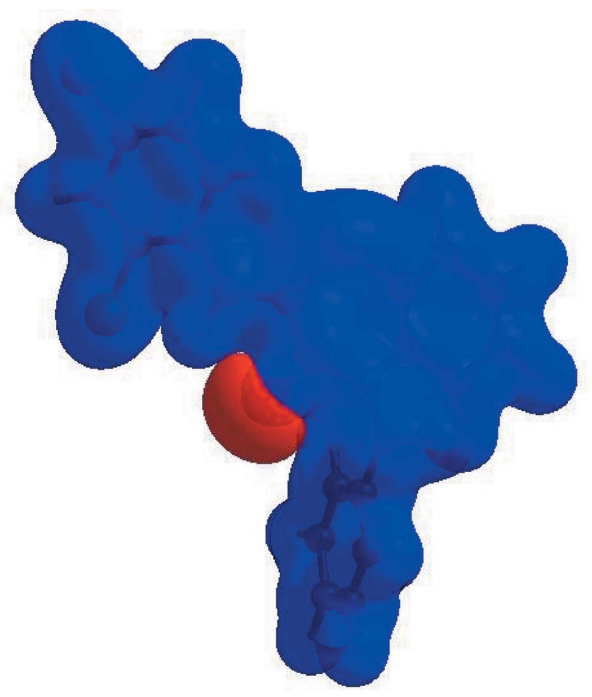

View of the 3D Hirshfeld surface of the title compound, plotted over electrostatic potential energy in the range -0.0500 to 0.0500 a.u., using the STO-3G basis set at the Hartree-Fock level of theory. Hydrogenbond donors and acceptors are shown as blue and red regions around the atoms corresponding to positive and negative potentials, respectively.
Table 2

Selected interatomic distances $(\AA)$.

\begin{tabular}{llll}
\hline $\mathrm{C} 11 \cdots \mathrm{Cl} 1^{\mathrm{i}}$ & $3.2439(5)$ & $\mathrm{C} 6 \cdots \mathrm{C} 22$ & $3.4830(18)$ \\
$\mathrm{C} 11 \cdots \mathrm{C} 14^{\mathrm{ii}}$ & $3.4981(14)$ & $\mathrm{C} 6 \cdots \mathrm{C} 12^{\mathrm{v}}$ & $3.5828(18)$ \\
$\mathrm{C} 11 \cdots \mathrm{H} 9$ & $2.647(16)$ & $\mathrm{C} 7 \cdots \mathrm{C} 22$ & $3.4391(18)$ \\
$\mathrm{C} 12 \cdots \mathrm{H} 19^{\mathrm{iii}}$ & $2.96(2)$ & $\mathrm{C} 10 \cdots \mathrm{C} 12^{\mathrm{ii}}$ & $3.4871(18)$ \\
$\mathrm{C} 2 \cdots \mathrm{H} 9^{\mathrm{ii}}$ & $3.044(16)$ & $\mathrm{C} 14 \cdots \mathrm{C} 20^{\mathrm{iv}}$ & $3.572(2)$ \\
$\mathrm{C} 12 \cdots \mathrm{H} 4^{\mathrm{iv}}$ & $3.138(18)$ & $\mathrm{C} 5 \cdots \mathrm{H} 16 A$ & $2.563(16)$ \\
$\mathrm{S} 1 \cdots \mathrm{C} 2^{\mathrm{v}}$ & $3.5832(5)$ & $\mathrm{C} 6 \cdots \mathrm{H} 22$ & $2.904(15)$ \\
$\mathrm{S} 1 \cdots \mathrm{Cl} 2^{\mathrm{v}}$ & $3.5832(5)$ & $\mathrm{C} 8 \cdots \mathrm{H} 15$ & $2.929(18)$ \\
$\mathrm{S} 1 \cdots \mathrm{N} 1$ & $3.0801(11)$ & $\mathrm{C} 16 \cdots \mathrm{H} 5$ & $2.556(18)$ \\
$\mathrm{S} 1 \cdots \mathrm{C} 15$ & $3.1625(14)$ & $\mathrm{C} 17 \cdots \mathrm{H} 5$ & $2.829(18)$ \\
$\mathrm{S} 1 \cdots \mathrm{C} 13^{\mathrm{v}}$ & $3.6033(13)$ & $\mathrm{C} 18 \cdots \mathrm{H} 3^{\mathrm{vi}}$ & $2.998(17)$ \\
$\mathrm{S} 1 \cdots \mathrm{H} 15$ & $2.578(18)$ & $\mathrm{C} 21 \cdots \mathrm{H} 12^{\mathrm{i}}$ & $2.845(18)$ \\
$\mathrm{O} 1 \cdots \mathrm{C} 17$ & $3.2096(16)$ & $\mathrm{H} 14 \cdots \mathrm{C} 20^{\mathrm{iv}}$ & $2.964(18)$ \\
$\mathrm{O} 1 \cdots \mathrm{C} 4^{\mathrm{vi}}$ & $3.3346(17)$ & $\mathrm{H} 14 \cdots \mathrm{C} 21^{\mathrm{iv}}$ & $2.899(18)$ \\
$\mathrm{O} 1 \cdots \mathrm{H} 9$ & $2.406(16)$ & $\mathrm{H} 14 \cdots \mathrm{C} 22^{\mathrm{iv}}$ & $2.990(18)$ \\
$\mathrm{O} 1 \cdots \mathrm{H} 16 B$ & $2.345(16)$ & $\mathrm{H} 15 \cdots \mathrm{C} 19^{\mathrm{iv}}$ & $2.951(18)$ \\
$\mathrm{O} 1 \cdots \mathrm{H} 4^{\mathrm{vi}}$ & $2.51(2)$ & $\mathrm{H} 16 B \cdots \mathrm{S} 1^{\mathrm{v}}$ & $2.852(16)$ \\
$\mathrm{N} 1 \cdots \mathrm{S} 1$ & $3.0801(11)$ & $\mathrm{H} 16 B \cdots \mathrm{C} 1^{\mathrm{v}}$ & $2.973(16)$ \\
$\mathrm{N} 1 \cdots \mathrm{H} 22$ & $2.552(15)$ & $\mathrm{H} 18 \cdots \mathrm{C} 6^{\mathrm{v}}$ & $2.934(19)$ \\
$\mathrm{C} 1 \cdots \mathrm{C} 12^{\mathrm{v}}$ & $3.4639(18)$ & $\mathrm{H} 5 \cdots \mathrm{H} 16 A$ & $2.16(2)$ \\
$\mathrm{C} 1 \cdots \mathrm{C} 13^{\mathrm{v}}$ & $3.4372(18)$ & $\mathrm{H} 12 \cdots \mathrm{H} 21^{\mathrm{i}}$ & $2.46(3)$ \\
$\mathrm{C} 2 \cdots \mathrm{C} 12^{\mathrm{v}}$ & $3.541(2)$ & $\mathrm{H} 15 \cdots \mathrm{H} 21^{\mathrm{viii}}$ & $2.51(3)$ \\
$\mathrm{C} 3 \cdots \mathrm{C} 3^{\mathrm{vii}}$ & $3.485(2)$ & $\mathrm{H} 16 B \cdots \mathrm{H} 18$ & $2.51(2)$ \\
$\mathrm{C} 5 \cdots \mathrm{C} 22$ & $3.4988(19)$ & $\mathrm{H} 18 \cdots \mathrm{H} 22^{\mathrm{v}}$ & $2.53(2)$ \\
$\mathrm{C} 5 \cdots \mathrm{C} 17$ & $3.4201(18)$ & & \\
\hline & & &
\end{tabular}

Symmetry codes: (i) $-x+1,-y+1,-z+1$; (ii) $-x,-y+1,-z+1$; $\quad$ (iii) $x-1, y, z+1$; (iv) $x-1,-y+\frac{1}{2}, z+\frac{1}{2}$; (v) $x,-y+\frac{1}{2}, z-\frac{1}{2}$; (vi) $-x+1, y+\frac{1}{2},-z+\frac{1}{2}$; (vii) $-x+1,-y,-z+1$; (viii) $x-1, y, z$.

as the respective donors and/or acceptors; they also appear as blue and red regions corresponding to positive and negative potentials on the HS mapped over electrostatic potential (Spackman et al., 2008; Jayatilaka et al., 2005), as shown in Fig. 4. The blue regions indicate the positive electrostatic potential (hydrogen-bond donors), while the red regions indicate the negative electrostatic potential (hydrogen-bond acceptors). The shape-index of the HS is a tool to visualize the $\pi-\pi$ stacking by the presence of adjacent red and blue triangles; if there are no adjacent red and/or blue triangles, then there are no $\pi-\pi$ interactions. Fig. 5 clearly suggest that there are $\pi-\pi$ interactions in (I). The overall two-dimensional (2D) fingerprint plot (Fig. $6 a$ ) and those delineated into $\mathrm{H} \cdots \mathrm{H}$, $\mathrm{H} \cdots \mathrm{C} / \mathrm{C} \cdots \mathrm{H}, \mathrm{H} \cdots \mathrm{Cl} / \mathrm{Cl} \cdots \mathrm{H}, \mathrm{O} \cdots \mathrm{H} / \mathrm{H} \cdots \mathrm{O}, \mathrm{C} \cdots \mathrm{C}, \mathrm{S} \cdots \mathrm{H} /$ $\mathrm{H} \cdots \mathrm{S}$ and $\mathrm{Cl} \cdots \mathrm{C} / \mathrm{C} \cdots \mathrm{Cl}$ contacts (McKinnon et al., 2007) are illustrated in Figs. 6(b)-(h), respectively, together with their

Figure 5

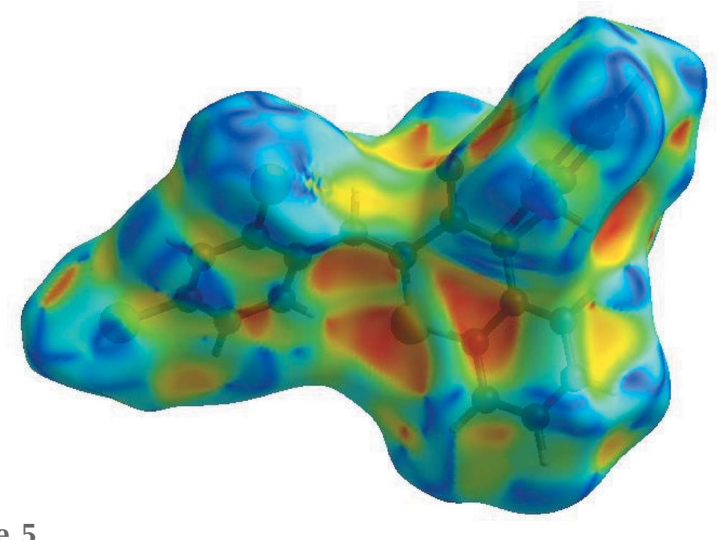

Hirshfeld surface of the title compound plotted over shape-index. 
relative contributions to the Hirshfeld surface. The most important interaction is $\mathrm{H} \cdots \mathrm{H}$, contributing $29.1 \%$ to the overall crystal packing, which is reflected in Fig. $6(b)$ as widely scattered points of high density due to the large hydrogen content of the molecule with the tip at $d_{\mathrm{e}}=d_{\mathrm{i}}=1.17 \AA$, due to the short interatomic $\mathrm{H} \cdots \mathrm{H}$ contacts (Table 2). In the presence of $\mathrm{C}-\mathrm{H} \cdots \pi$ interactions, the pairs of characteristic wings resulting in the fingerprint plot delineated into $\mathrm{H} \cdots \mathrm{C} /$ C. . H contacts (Fig. $6 c$ ), with a $27.5 \%$ contribution to the HS, arises from the $\mathrm{H} \cdots \mathrm{C} / \mathrm{C} \cdots \mathrm{H}$ contacts (Table 2) and are viewed as pairs of spikes with the tips at $d_{\mathrm{e}}+d_{\mathrm{i}}=2.82$ and $2.78 \AA$ for thin and thick spikes, respectively. The pair of scattered points of the wings resulting in the fingerprint plots delineated into $\mathrm{H} \cdots \mathrm{Cl} / \mathrm{Cl} \cdots \mathrm{H}$ (Fig. $6 d$ ), with a $20.6 \%$ contribution to the HS, has a symmetrical distribution of points with the edges at $d_{\mathrm{e}}+d_{\mathrm{i}}=2.78 \AA$ arising from the
$\mathrm{H} \cdots \mathrm{Cl} / \mathrm{Cl} \cdots \mathrm{H}$ contacts (Table 2). The pair of characteristic wings resulting in the fingerprint plot delineated into $\mathrm{O} \cdots \mathrm{H} /$ $\mathrm{H}$. . O contacts (Fig. $6 e$ ), with a $7.0 \%$ contribution to the HS, arises from the $\mathrm{O} \cdots \mathrm{H} / \mathrm{H} \cdots \mathrm{O}$ contacts (Table 2) and is viewed as a pair of spikes with the tips at $d_{\mathrm{e}}+d_{\mathrm{i}}=2.35 \AA$. The $\mathrm{C} \cdots \mathrm{C}$ contacts (Fig. $6 f$ ) have an arrow-shaped distribution of points with the tip at $d_{\mathrm{e}}=d_{\mathrm{i}}=1.7 \AA$. Finally, the characteristic wings resulting in the fingerprint plots delineated into $\mathrm{S} \cdots \mathrm{H} / \mathrm{H} \cdots \mathrm{S}$ and $\mathrm{Cl} \cdots \mathrm{C} / \mathrm{C} \cdots \mathrm{Cl}$ contacts (Figs. $6 \mathrm{~g}$ and $6 h$ ), with 4.0 and $2.2 \%$ contributions to the HS, arise from the $\mathrm{S} \cdots \mathrm{H} / \mathrm{H} \cdots \mathrm{S}$ and $\mathrm{Cl} \cdots \mathrm{C} / \mathrm{C} \cdots \mathrm{Cl}$ contacts (Table 2$)$ and are viewed with the tips at $d_{\mathrm{e}}=d_{\mathrm{i}}=2.70 \AA$ and $d_{\mathrm{e}}+d_{\mathrm{i}}=3.46 \AA$, respectively.

The Hirshfeld surface representations with the function $d_{\text {norm }}$ plotted onto the surface are shown for the $\mathrm{H} \cdots \mathrm{H}$, $\mathrm{H} \cdots \mathrm{C} / \mathrm{C} \cdots \mathrm{H}, \quad \mathrm{H} \cdots \mathrm{Cl} / \mathrm{Cl} \cdots \mathrm{H}, \quad \mathrm{O} \cdots \mathrm{H} / \mathrm{H} \cdots \mathrm{O}, \quad \mathrm{C} \cdots \mathrm{C}$ and $\mathrm{S} \cdots \mathrm{H} / \mathrm{H} \cdots \mathrm{S}$ interactions in Figs. $7(a)-(f)$, respectively.
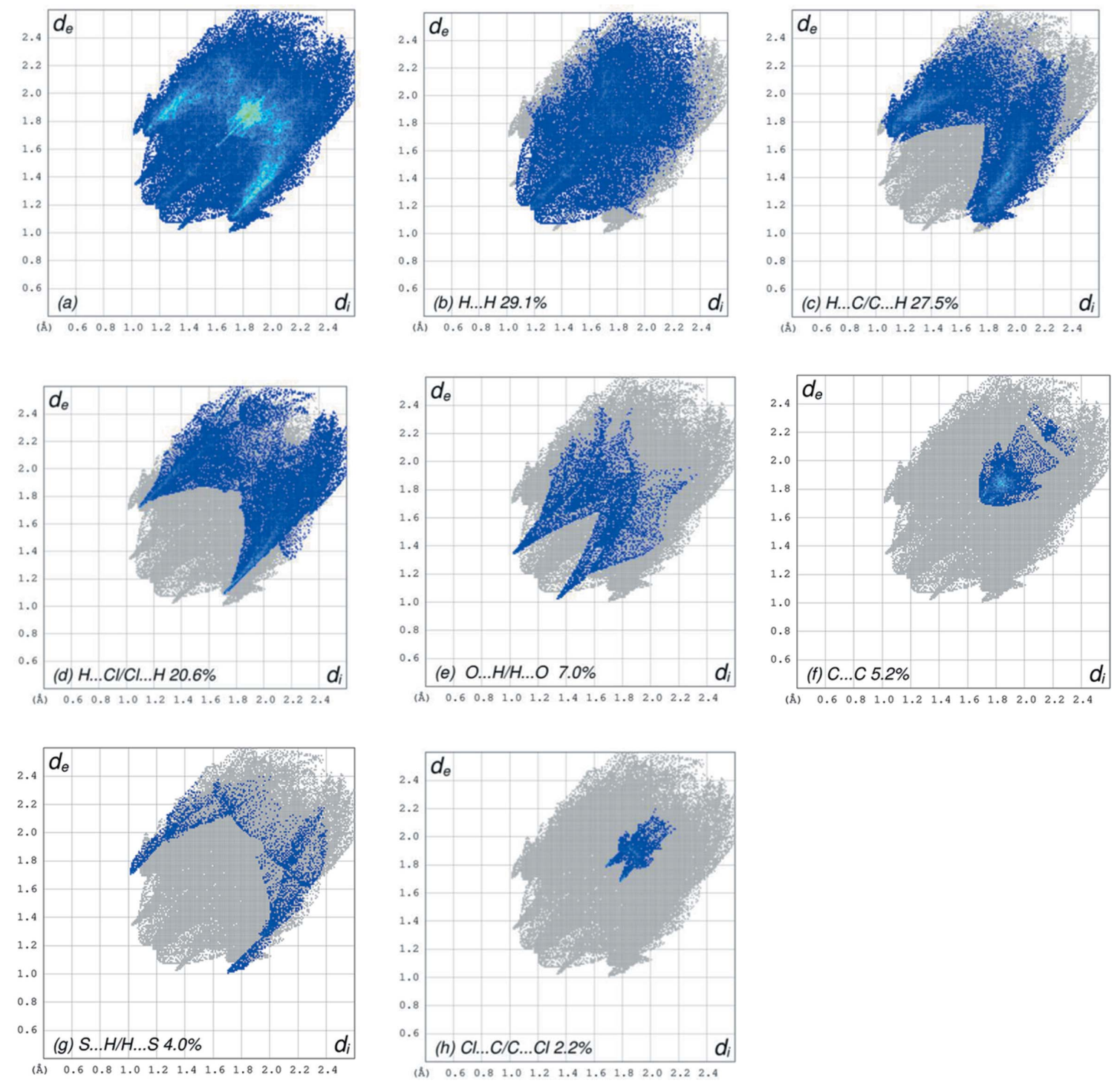

Figure 6

The full 2D fingerprint plots for the title compound, showing $(a)$ all interactions, and delineated into $(b) \mathrm{H} \cdots \mathrm{H},(c) \mathrm{H} \cdots \mathrm{C} / \mathrm{C} \cdots \mathrm{H},(d) \mathrm{H} \cdots \mathrm{Cl} / \mathrm{Cl} \cdots \mathrm{H},(e)$ $\mathrm{O} \cdots \mathrm{H} / \mathrm{H} \cdots \mathrm{O},(f) \mathrm{C} \cdots \mathrm{C},(g) \mathrm{S} \cdots \mathrm{H} / \mathrm{H} \cdots \mathrm{S}$ and $(h) \mathrm{Cl} \cdots \mathrm{C} / \mathrm{C} \cdots \mathrm{Cl}$ interactions. The $d_{\mathrm{i}}$ and $d_{\mathrm{e}}$ values are the closest internal and external distances (in $\AA$ ) from given points on the Hirshfeld surface contacts. 


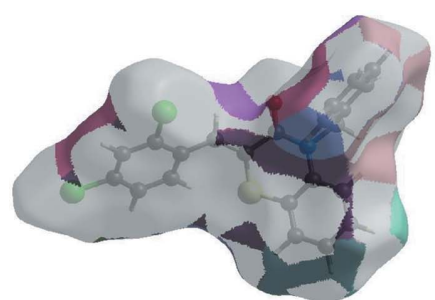

(a)

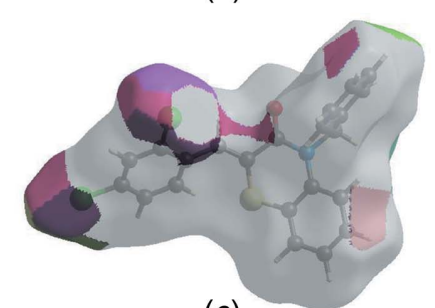

(c)

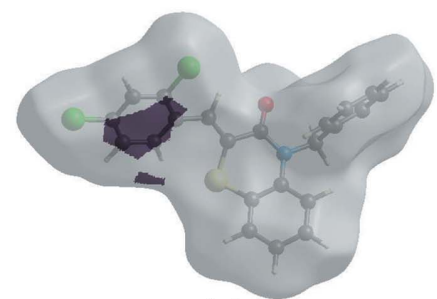

(e)

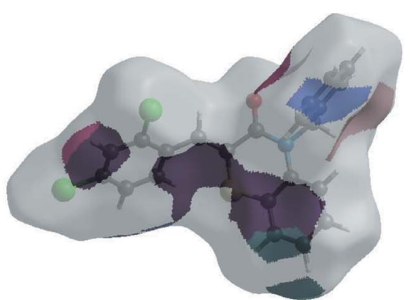

(b)

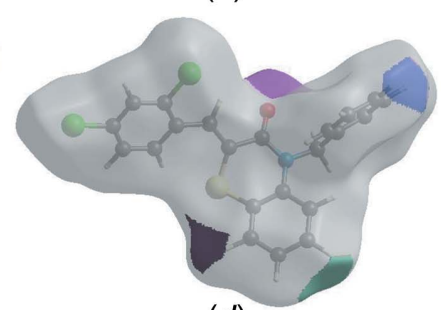

(d)

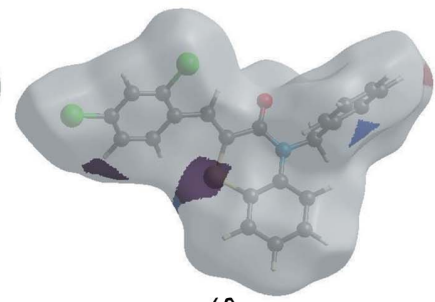

$(f)$
Figure 7

The Hirshfeld surface representations with the function $d_{\text {norm }}$ plotted onto the surface for $(a) \mathrm{H} \cdots \mathrm{H},(b) \mathrm{H} \cdots \mathrm{C} / \mathrm{C} \cdots \mathrm{H},(c) \mathrm{H} \cdots \mathrm{Cl} / \mathrm{Cl} \cdots \mathrm{H},(d)$ $\mathrm{O} \cdots \mathrm{H} / \mathrm{H} \cdots \mathrm{O},(e) \mathrm{C} \cdots \mathrm{C}$ and $(f) \mathrm{S} \cdots \mathrm{H} / \mathrm{H} \cdots \mathrm{S}$ interactions.

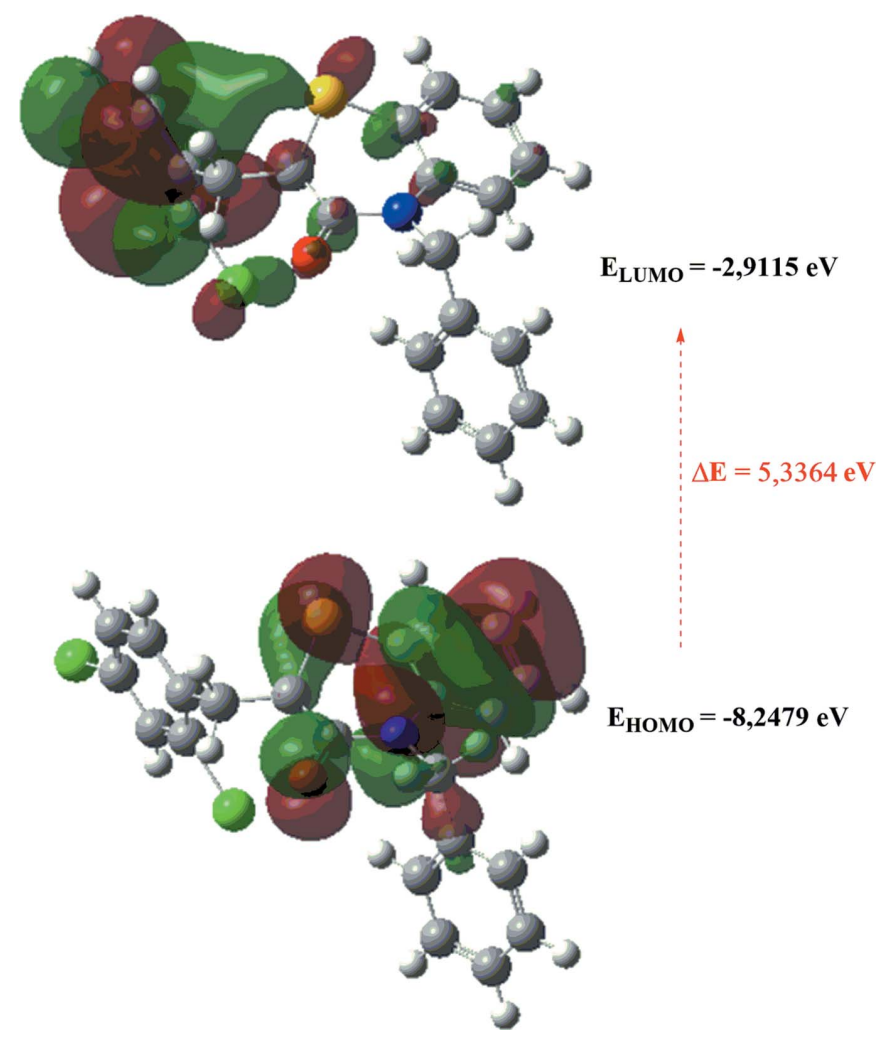

Figure 8

The energy band gap of the title compound.
Table 3

Comparison of the selected (X-ray and DFT) geometric data $\left(\AA,^{\circ}\right)$.

\begin{tabular}{lll}
\hline Bonds/angles & X-ray & B3LYP/6-311G(d,p) \\
\hline C11-C11 & $1.7357(13)$ & 1.80981 \\
C12-C13 & $1.7382(13)$ & 1.80489 \\
S1-C8 & $1.7525(12)$ & 1.80120 \\
S1-C1 & $1.7561(13)$ & 1.82629 \\
O1-C7 & $1.2228(16)$ & 1.23968 \\
N1-C7 & $1.3759(16)$ & 1.38157 \\
N1-C6 & $1.4192(16)$ & 1.41776 \\
N1-C16 & $1.4661(16)$ & 1.47048 \\
C8-S1-C1 & $100.14(6)$ & 98.69028 \\
C7-N1-C6 & $125.51(10)$ & 124.58623 \\
C7-N1-C16 & $115.14(10)$ & 116.12685 \\
C6-N1-C16 & $119.20(10)$ & 119.26679 \\
C2-C1-C6 & $120.71(12)$ & 121.24260 \\
C2-C1-S1 & $117.26(10)$ & 117.48822 \\
C6-C1-S1 & $122.02(10)$ & 121.26667 \\
\hline
\end{tabular}

The Hirshfeld surface analysis confirms the importance of $\mathrm{H}$-atom contacts in establishing the packing. The large number of $\mathrm{H} \cdots \mathrm{H}, \mathrm{H} \cdots \mathrm{C} / \mathrm{C} \cdots \mathrm{H}, \mathrm{H} \cdots \mathrm{Cl} / \mathrm{Cl} \cdots \mathrm{H}$ and $\mathrm{O} \cdots \mathrm{H} / \mathrm{H} \cdots \mathrm{O}$ interactions suggest that van der Waals interactions and hydrogen bonding play the biggest roles in the crystal packing (Hathwar et al., 2015).

\section{Interaction energy calculations}

The intermolecular interaction energies are calculated using CE-B3LYP/6-31G(d,p) energy model available in CrystalExplorer (CE) (Version 17.5; Turner et al., 2017), where a cluster of molecules would need to be generated by applying crystallographic symmetry operations with respect to a selected central molecule within a default radius of $3.8 \AA$ (Turner et al., 2014). The total intermolecular energy $\left(E_{\mathrm{tot}}\right)$ is the sum of the electrostatic $\left(E_{\text {ele }}\right)$, polarization $\left(E_{\mathrm{pol}}\right)$, dispersion $\left(E_{\mathrm{dis}}\right)$ and exchange-repulsion $\left(E_{\mathrm{rep}}\right)$ energies (Turner et al., 2015), with scale factors of 1.057, 0.740, 0.871 and 0.618 , respectively (Mackenzie et al., 2017). Hydrogen-bonding interaction energies (in $\mathrm{kJ} \mathrm{mol}^{-1}$ ) were calculated as -20.3 $\left(E_{\text {ele }}\right),-2.6\left(E_{\mathrm{pol}}\right),-79.4\left(E_{\mathrm{dis}}\right), 60.7\left(E_{\mathrm{rep}}\right)$ and $-55.0\left(E_{\mathrm{tot}}\right)$ for $\mathrm{C}-\mathrm{H}_{\mathrm{Bnz}} \cdots \mathrm{O}_{\mathrm{Thz}}$ hydrogen-bonding interactions, and -5.8 $\left(E_{\text {ele }}\right),-1.0\left(E_{\mathrm{pol}}\right),-51.0\left(E_{\mathrm{dis}}\right), 39.3\left(E_{\mathrm{rep}}\right)$ and $-27.1\left(E_{\mathrm{tot}}\right)$ for $\mathrm{C}-\mathrm{H}_{\text {Methy }} \cdots \mathrm{S}_{\text {Thz }}$ hydrogen-bonding interactions.

\section{DFT calculations}

The optimized structure of (I) in the gas phase was generated theoretically via density functional theory (DFT) using standard B3LYP functional and 6-311G(d,p) basis-set calculations (Becke, 1993), as implemented in GAUSSIAN09 (Frisch et al., 2009). The theoretical and experimental results were in good agreement (Table 3). The highest-occupied molecular orbital (HOMO), acting as an electron donor, and the lowest-unoccupied molecular orbital (LUMO), acting as an electron acceptor, are very important parameters for quantum chemistry. When the energy gap is small, the molecule is highly polarizable and has high chemical reactivity. The DFT calculations provide some important information on the reactivity 
Table 4

Calculated energies..

\begin{tabular}{ll}
\hline Molecular Energy (a.u.) (eV) & Compound (I) \\
\hline Total Energy $T E(\mathrm{eV})$ & $-62249,6662$ \\
$E_{\text {HOMO }}(\mathrm{eV})$ & -8.2479 \\
$E_{\text {Lumo }}(\mathrm{eV})$ & -2.9115 \\
Gap $\Delta E(\mathrm{eV})$ & 5.3364 \\
Dipole moment, $\mu($ Debye $)$ & 3.4723 \\
Ionization potential, $I(\mathrm{eV})$ & 8.2479 \\
Electron affinity, $A$ & 2.9115 \\
Electro negativity, $\chi$ & 5.3364 \\
Hardness, $\eta$ & 2.6682 \\
Electrophilicity index, $\omega$ & 5.8340 \\
Softness, $\sigma$ & 0.3748 \\
Fraction of electron transferred, $\Delta N$ & 0.2662
\end{tabular}

and site selectivity of the molecular framework. $E_{\text {Hомо }}$ and $E_{\text {LUMO }}$ clarifying the inevitable charge exchange collaboration inside the studied material, electronegativity $(\chi)$, hardness $(\eta)$, potential $(\mu)$, electrophilicity $(\omega)$ and softness $(\sigma)$ are recorded in Table 4 . The significance of $\eta$ and $\sigma$ is to evaluate both the reactivity and stability. The electron transition from the HOMO to the LUMO energy level is shown in Fig. 8. The HOMO and LUMO are localized in the plane extending from the whole molecule. The energy band gap $\left(\Delta E=E_{\mathrm{LuMO}}-\right.$ $\left.E_{\mathrm{HOMO}}\right)$ of the molecule was about $5.3364 \mathrm{eV}$, and the frontier molecular orbital (FMO) energies, $E_{\mathrm{HOMO}}$ and $E_{\mathrm{LUMO}}$, were -8.2479 and $-2.9115 \mathrm{eV}$, respectively.

Table 5

Experimental details.

\begin{tabular}{ll}
\hline Crystal data & \\
Chemical formula & $\mathrm{C}_{22} \mathrm{H}_{15} \mathrm{Cl}_{2} \mathrm{NOS}$ \\
$M_{\mathrm{r}}$ & 412.31 \\
Crystal system, space group & Monoclinic, $P 2_{1} / c$ \\
Temperature $(\mathrm{K})$ & 150 \\
$a, b, c(\AA)$ & $9.0373(7), 16.6798(13), 12.511(1)$ \\
$\beta\left({ }^{\circ}\right)$ & $95.982(2)$ \\
$V\left(\AA^{3}\right)$ & $1875.6(3)$ \\
$Z$ & 4 \\
Radiation type & $\mathrm{Cu} K \alpha$ \\
$\mu\left(\mathrm{mm}^{-1}\right)$ & 4.25 \\
Crystal size $(\mathrm{mm})$ & $0.15 \times 0.13 \times 0.09$ \\
& \\
Data collection & Bruker D8 VENTURE PHOTON \\
Diffractometer & $100 \mathrm{CMOS}$ \\
& Numerical $(S A D A B S ;$ Krause $e t$ \\
Absorption correction & $a l ., 2015)$ \\
& $0.59,0.70$ \\
$T_{\text {min }}, T_{\text {max }}$ & $48886,3847,3650$ \\
No. of measured, independent and & \\
$\quad$ observed $[I>2 \sigma(I)]$ reflections & 0.038 \\
$R_{\text {int }}(\text { sin } \theta / \lambda)_{\text {max }}\left(\AA^{-1}\right)$ & 0.625 \\
& \\
Refinement & \\
$R\left[F^{2}>2 \sigma\left(F^{2}\right)\right], w R\left(F^{2}\right), S$ & $0.026,0.070,1.05$ \\
No. of reflections & 3847 \\
No. of parameters & 304 \\
H-atom treatment & All H-atom parameters refined \\
$\Delta \rho_{\text {max }}, \Delta \rho_{\text {min }}\left(\mathrm{e} \AA^{-3}\right)$ & $0.22,-0.26$ \\
\hline
\end{tabular}

Computer programs: APEX3 (Bruker, 2016), SAINT (Bruker, 2016), SHELXT (Sheldrick, 2015a), SHELXL2018 (Sheldrick, 2015b), DIAMOND (Brandenburg \& Putz, 2012) and SHELXTL (Bruker, 2016).

\section{Database survey}

A search in the Cambridge Structural Database (Groom et al., 2016; updated to June 2019) for compounds containing the fragment II (with $R_{1}=\mathrm{Ph}$ and $R_{2}=\mathrm{C}$; see Scheme 2) gave 14 hits. With $R_{1}=\mathrm{Ph}$ and $R_{2}=\mathrm{CH}_{2} \mathrm{C} \equiv \mathrm{CH}$ (IIa) (Sebbar et al., 2014a), $\mathrm{CH}_{2} \mathrm{COOH}$ (IIb) (Sebbar et al., 2016c), 2-(2-oxo-1,3oxazolidin-3-yl)ethyl (IIc) (Sebbar et al., 2016b) and (3phenyl-4,5-dihydro-1,2-oxazol-5-yl)methyl (IIf) (Sebbar et al., $2015 b)$ ] (Scheme 2), there are other examples with $R_{1}=4$ $\mathrm{FC}_{6} \mathrm{H}_{4}$ and $R_{2}=\mathrm{CH}_{2} \mathrm{C} \equiv \mathrm{CH}$ (IIa) (Hni et al., 2019a), $R_{1}=4$ $\mathrm{ClC}_{6} \mathrm{H}_{4}$ and $R_{2}=\mathrm{CH}_{2} \mathrm{Ph} 2$ (IId) (Ellouz et al., 2016c), and $R_{1}=$ 2- $\mathrm{ClC}_{6} \mathrm{H}_{4}$ and $R_{2}=\mathrm{CH}_{2} \mathrm{C} \equiv \mathrm{CH}$ (IIa) (Sebbar et al., 2017) (Scheme 2). In all compounds, the configuration about the benzylidene-group $\mathrm{C}=\mathrm{CHC}_{6} \mathrm{H}_{5}$ bond is $Z$, and in the majority of these, the heterocyclic ring is quite nonplanar, with the dihedral angle between the plane defined by the benzene ring plus the $\mathrm{N}$ and $\mathrm{S}$ atoms, and that defined by the $\mathrm{N}$ and $\mathrm{S}$ atoms and the other two $\mathrm{C}$ atoms separating them ranging from $\mathrm{ca} 29$ (for IIa) to $36^{\circ}$ (for IIf). The other two (IIa and IIc) have the benzothiazine unit nearly planar, with corresponding dihedral angles of $c a 3-4^{\circ}$.<smiles>[R7]C=C1Sc2ccccc2N([R2])C1=O</smiles>

II

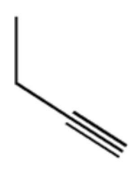

IIa

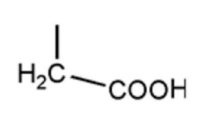

IIb<smiles>CCCN1CCOC1=O</smiles>

IIc<smiles>CCc1ccccc1</smiles>

IId<smiles>CCC1CC(c2ccccc2)=NO1</smiles>

IIf
Scheme 2

\section{Synthesis and crystallization}

To a solution of (Z)-2-(2,4-dichlorobenzylidene)-2H-1,4benzothiazin-3(4H)-one $(3.21 \mathrm{mmol})$, benzyl chloride $(6.52 \mathrm{mmol})$ and potassium carbonate $(6.51 \mathrm{mmol})$ in dimethylformamide (DMF; $17 \mathrm{ml}$ ) was added a catalytic amount of tetra- $n$-butylammonium bromide $(0.33 \mathrm{mmol})$. The mixture was stirred for $24 \mathrm{~h}$. The solid material was removed by filtration and the solvent evaporated under vacuum. The solid product was purified by recrystallization from ethanol to afford colourless crystals in $82 \%$ yield. 


\section{Refinement}

The experimental details, including the crystal data, data collection and refinement, are summarized in Table 5. $\mathrm{H}$ atoms were located in a difference Fourier map and refined freely.

\section{Acknowledgements}

The support of NSF-MRI for the purchase of the diffractometer and Tulane University for support of the Tulane Crystallography Laboratory are gratefully acknowledged.

\section{Funding information}

Funding for this research was provided by: NSF-MRI (grant No. 1228232); Hacettepe University Scientific Research Project Unit (grant No. 013 D04 602004 to TH).

\section{References}

Armenise, D., Muraglia, M., Florio, M. A., Laurentis, N. D., Rosato, A., Carrieri, A., Corbo, F. \& Franchini, C. (2012). Mol. Pharmacol. 50, $1178-1188$.

Becke, A. D. (1993). J. Chem. Phys. 98, 5648-5652.

Bernstein, J., Davis, R. E., Shimoni, L. \& Chang, N. L. (1995). Angew. Chem. Int. Ed. Engl. 34, 1555-1573.

Brandenburg, K. \& Putz, H. (2012). DIAMOND. Crystal Impact GbR, Bonn, Germany.

Bruker (2016). APEX3, SAINT, SADABS and SHELXTL. Bruker AXS Inc., Madison, Wisconsin, USA.

Cremer, D. \& Pople, J. A. (1975). J. Am. Chem. Soc. 97, 1354-1358.

Ellouz, M., Elmsellem, H., Sebbar, N. K., Steli, H., Al Mamari, K., Nadeem, A., Ouzidan, Y., Essassi, E. M., Abdel-Rahaman, I. \& Hristov, P. (2016b). J. Mater. Environ. Sci. 7, 2482-2497.

Ellouz, M., Sebbar, N. K., Boulhaoua, M., Essassi, E. M. \& Mague, J. T. (2017a). IUCrData, 2, x170646.

Ellouz, M., Sebbar, N. K., Elmsellem, H., Steli, H., Fichtali, I., Mohamed, A. M. M., Mamari, K. A., Essassi, E. M. \& AbdelRahaman, I. (2016a). J. Mater. Environ. Sci. 7, 2806-2819.

Ellouz, M., Sebbar, N. K., Essassi, E. M., Ouzidan, Y., Mague, J. T. \& Zouihri, H. (2016c). IUCrData, 1, x160764.

Ellouz, M., Sebbar, N. K., Fichtali, I., Ouzidan, Y., Mennane, Z., Charof, R., Mague, J. T., Urrutigoïty, M. \& Essassi, E. M. (2018). Chem. Cent. J. 12, 123.

Ellouz, M., Sebbar, N. K., Ouzidan, Y., Essassi, E. M. \& Mague, J. T. (2017b). IUCrData, 2, x170097.

Frisch, M. J., et al. (2009). GAUSSIAN09. Gaussian Inc., Wallingford, CT, USA.

Gowda, J., Khader, A. M. A., Kalluraya, B., Shree, P. \& Shabaraya, A. R. (2011). Eur. J. Med. Chem. 46, 4100-4106.

Groom, C. R., Bruno, I. J., Lightfoot, M. P. \& Ward, S. C. (2016). Acta Cryst. B72, 171-179.

Gupta, R. R., Kumar, R. \& Gautam, R. K. (1985). J. Fluor. Chem. 28, 381-385.

Gupta, V. \& Gupta, R. R. (1991). J. Prakt. Chem. 333, 153-156.

Hathwar, V. R., Sist, M., Jørgensen, M. R. V., Mamakhel, A. H., Wang, X., Hoffmann, C. M., Sugimoto, K., Overgaard, J. \& Iversen, B. B. (2015). IUCrJ, 2, 563-574.
Hirshfeld, H. L. (1977). Theor. Chim. Acta, 44, 129-138.

Hni, B., Sebbar, N. K., Hökelek, T., El Ghayati, L., Bouzian, Y., Mague, J. T. \& Essassi, E. M. (2019b). Acta Cryst. E75, 593-599.

Hni, B., Sebbar, N. K., Hökelek, T., Ouzidan, Y., Moussaif, A., Mague, J. T. \& Essassi, E. M. (2019a). Acta Cryst. E75, 372-377.

Jayatilaka, D., Grimwood, D. J., Lee, A., Lemay, A., Russel, A. J., Taylor, C., Wolff, S. K., Cassam-Chenai, P. \& Whitton, A. (2005). TONTO - A System for Computational Chemistry. Available at: http://hirshfeldsurface.net/.

Krause, L., Herbst-Irmer, R., Sheldrick, G. M. \& Stalke, D. (2015). J. Appl. Cryst. 48, 3-10.

Mackenzie, C. F., Spackman, P. R., Jayatilaka, D. \& Spackman, M. A. (2017). IUCrJ, 4, 575-587.

Malagu, K., Boustie, J., David, M., Sauleau, J., Amoros, M., Girre, R. L. \& Sauleau, A. (1998). Pharm. Pharmacol. Commun. 4, 57-60.

McKinnon, J. J., Jayatilaka, D. \& Spackman, M. A. (2007). Chem. Commun. pp. 3814-3816.

Rathore, B. S. \& Kumar, M. (2006). Bioorg. Med. Chem. 14, 56785682.

Sebbar, N. K., Ellouz, M., Essassi, E. M., Ouzidan, Y. \& Mague, J. T. (2015a). Acta Cryst. E71, o999.

Sebbar, N. K., Ellouz, M., Essassi, E. M., Saadi, M. \& El Ammari, L. (2015b). Acta Cryst. E71, o423-o424.

Sebbar, N. K., Ellouz, M., Essassi, E. M., Saadi, M. \& El Ammari, L. (2016a). IUCrData, 1, x161012.

Sebbar, N. K., Ellouz, M., Mague, J. T., Ouzidan, Y., Essassi, E. M. \& Zouihri, H. (2016c). IUCrData, 1, x160863.

Sebbar, N. K., Ellouz, M., Ouzidan, Y., Kaur, M., Essassi, E. M. \& Jasinski, J. P. (2017). IUCrData, 2, x170889.

Sebbar, N. K., Mekhzoum, M. E. M., Essassi, E. M., Zerzouf, A., Talbaoui, A., Bakri, Y., Saadi, M. \& Ammari, L. E. (2016b). Res. Chem. Intermed. 42, 6845-6862.

Sebbar, N. K., Zerzouf, A., Essassi, E. M., Saadi, M. \& El Ammari, L. (2014a). Acta Cryst. E70, o614.

Sheldrick, G. M. (2015a). Acta Cryst. A71, 3-8.

Sheldrick, G. M. (2015b). Acta Cryst. C71, 3-8.

Spackman, M. A. \& Jayatilaka, D. (2009). CrystEngComm, 11, 19-32.

Spackman, M. A., McKinnon, J. J. \& Jayatilaka, D. (2008). CrystEngComm, 10, 377-388.

Tawada, H., Sugiyama, Y., Ikeda, H., Yamamoto, Y. \& Meguro, K. (1990). Chem. Pharm. Bull. 38, 1238-1245.

Trapani, G., Reho, A., Morlacchi, F., Latrofa, A., Marchini, P., Venturi, F. \& Cantalamessa, F. (1985). Farmaco Ed. Sci. 40, 369376.

Turner, M. J., Grabowsky, S., Jayatilaka, D. \& Spackman, M. A. (2014). J. Phys. Chem. Lett. 5, 4249-4255.

Turner, M. J., McKinnon, J. J., Wolff, S. K., Grimwood, D. J., Spackman, P. R., Jayatilaka, D. \& Spackman, M. A. (2017). CrystalExplorer17. University of Western Australia.

Turner, M. J., Thomas, S. P., Shi, M. W., Jayatilaka, D. \& Spackman, M. A. (2015). Chem. Commun. 51, 3735-3738.

Venkatesan, P., Thamotharan, S., Ilangovan, A., Liang, H. \& Sundius, T. (2016). Spectrochim. Acta A Mol. Biomol. Spectrosc. 153, 625636.

Vidal, A., Madelmont, J. C. \& Mounetou, E. A. (2006). Synthesis, 2006, 591-593.

Warren, B. K. \& Knaus, E. E. (1987). Eur. J. Med. Chem. 22, 411-415.

Zia-ur-Rehman, M., Choudary, J. A., Elsegood, M. R. J., Siddiqui, H. L. \& Khan, K. M. (2009). Eur. J. Med. Chem. 44, 1311-1316. 


\section{supporting information}

Acta Cryst. (2019). E75, 1650-1656 [https://doi.org/10.1107/S2056989019013586]

Crystal structure, Hirshfeld surface analysis and interaction energy and DFT studies of (2Z)-4-benzyl-2-(2,4-dichlorobenzylidene)-2H-1,4-benzothiazin-3(4H)-one

Nada Kheira Sebbar, Brahim Hni, Tuncer Hökelek, Mohamed Labd Taha, Joel T. Mague, Lhoussaine El Ghayati and El Mokhtar Essassi

Computing details

Data collection: APEX3 (Bruker, 2016); cell refinement: SAINT (Bruker, 2016); data reduction: SAINT (Bruker, 2016); program(s) used to solve structure: SHELXT (Sheldrick, 2015a); program(s) used to refine structure: SHELXL2018 (Sheldrick, 2015b); molecular graphics: DIAMOND (Brandenburg \& Putz, 2012); software used to prepare material for publication: SHELXTL (Bruker, 2016).

(2Z)-4-Benzyl-2-(2,4-dichlorobenzylidene)-2H-1,4-benzothiazin-3(4H)-one

Crystal data

$\mathrm{C}_{22} \mathrm{H}_{15} \mathrm{Cl}_{2} \mathrm{NOS}$

$M_{r}=412.31$

Monoclinic, $P 2{ }_{1} / c$

$a=9.0373(7) \AA$

$b=16.6798(13) \AA$

$c=12.511(1) \AA$

$\beta=95.982(2)^{\circ}$

$V=1875.6(3) \AA^{3}$

$Z=4$

Data collection

Bruker D8 VENTURE PHOTON 100 CMOS diffractometer

Radiation source: INCOATEC I $\mu \mathrm{S}$ micro-focus source

Mirror monochromator

Detector resolution: 10.4167 pixels $\mathrm{mm}^{-1}$

$\omega$ scans

Absorption correction: numerical

(SADABS; Krause et al., 2015)

Refinement

Refinement on $F^{2}$

Least-squares matrix: full

$R\left[F^{2}>2 \sigma\left(F^{2}\right)\right]=0.026$

$w R\left(F^{2}\right)=0.070$

$S=1.05$
$F(000)=848$

$D_{\mathrm{x}}=1.460 \mathrm{Mg} \mathrm{m}^{-3}$

$\mathrm{Cu} K \alpha$ radiation, $\lambda=1.54178 \AA$

Cell parameters from 9943 reflections

$\theta=4.4-43.5^{\circ}$

$\mu=4.25 \mathrm{~mm}^{-1}$

$T=150 \mathrm{~K}$

Block, colourless

$0.14 \times 0.13 \times 0.09 \mathrm{~mm}$

$T_{\min }=0.59, T_{\max }=0.70$

48886 measured reflections

3847 independent reflections

3650 reflections with $I>2 \sigma(I)$

$R_{\text {int }}=0.038$

$\theta_{\text {max }}=74.6^{\circ}, \theta_{\min }=4.4^{\circ}$

$h=-11 \rightarrow 11$

$k=-20 \rightarrow 20$

$l=-15 \rightarrow 15$

3847 reflections

304 parameters

0 restraints

Secondary atom site location: difference Fourier map 
Hydrogen site location: difference Fourier map All $\mathrm{H}$-atom parameters refined $w=1 /\left[\sigma^{2}\left(F_{\mathrm{o}}^{2}\right)+(0.0379 P)^{2}+0.6937 P\right]$

where $P=\left(F_{\mathrm{o}}^{2}+2 F_{\mathrm{c}}^{2}\right) / 3$

$$
\begin{aligned}
& (\Delta / \sigma)_{\max }=0.001 \\
& \Delta \rho_{\max }=0.22 \mathrm{e} \AA^{-3} \\
& \Delta \rho_{\min }=-0.26 \mathrm{e} \AA^{-3}
\end{aligned}
$$

\section{Special details}

Geometry. All esds (except the esd in the dihedral angle between two 1.s. planes) are estimated using the full covariance matrix. The cell esds are taken into account individually in the estimation of esds in distances, angles and torsion angles; correlations between esds in cell parameters are only used when they are defined by crystal symmetry. An approximate (isotropic) treatment of cell esds is used for estimating esds involving l.s. planes.

Refinement. Refinement of $\mathrm{F}^{2}$ against ALL reflections. The weighted R-factor $\mathrm{wR}$ and goodness of fit $\mathrm{S}$ are based on $\mathrm{F}^{2}$, conventional R-factors $R$ are based on $F$, with $F$ set to zero for negative $F^{2}$. The threshold expression of $F^{2}>2$ sigma $\left(F^{2}\right)$ is used only for calculating R-factors ( $\mathrm{gt}$ ) etc. and is not relevant to the choice of reflections for refinement. R-factors based

\begin{tabular}{|c|c|c|c|c|}
\hline & $x$ & $y$ & $z$ & $U_{\text {iso }} * / U_{\text {eq }}$ \\
\hline $\mathrm{Cl1}$ & $0.32725(3)$ & $0.51603(2)$ & 0.51778 & $0.03318(9)$ \\
\hline $\mathrm{Cl} 2$ & $-0.08376(4)$ & $0.45362(2)$ & 0.78449 (3) & $0.03443(10)$ \\
\hline $\mathrm{S} 1$ & $0.15102(3)$ & 0.21109 (2) & $0.37534(2)$ & $0.02451(9)$ \\
\hline $\mathrm{O} 1$ & $0.29675(11)$ & $0.36735(6)$ & $0.18264(8)$ & $0.0318(2)$ \\
\hline N1 & $0.36671(11)$ & $0.23777(6)$ & $0.20360(8)$ & $0.0231(2)$ \\
\hline $\mathrm{C} 1$ & $0.29233(13)$ & $0.14621(7)$ & $0.34225(10)$ & $0.0235(2)$ \\
\hline $\mathrm{C} 2$ & $0.30706(15)$ & $0.07308(8)$ & 0.39669 (11) & $0.0287(3)$ \\
\hline $\mathrm{H} 2$ & $0.2413(19)$ & $0.0621(10)$ & $0.4526(14)$ & $0.033(4)^{*}$ \\
\hline $\mathrm{C} 3$ & $0.41257(16)$ & $0.01777(8)$ & $0.37140(12)$ & 0.0327 \\
\hline $\mathrm{H} 3$ & $0.4187(18)$ & $-0.0323(10)$ & $0.4058(13)$ & $0.030(4)^{*}$ \\
\hline $\mathrm{C} 4$ & $0.50780(16)$ & $0.03719(8)$ & $0.29531(13)$ & $0.0330(3)$ \\
\hline $\mathrm{H} 4$ & $0.579(2)$ & $-0.0001(12)$ & $0.2780(15)$ & $0.042(5)^{*}$ \\
\hline $\mathrm{C} 5$ & $0.49570(15)$ & $0.11045(8)$ & $0.24245(11)$ & 0.0285 \\
\hline H5 & $0.5655(19)$ & $0.1230(11)$ & $0.1921(13)$ & $0.035(4)^{*}$ \\
\hline C6 & $0.38507(13)$ & $0.16533(7)$ & $0.26301(10)$ & $0.0233(2)$ \\
\hline $\mathrm{C} 7$ & $0.29726(13)$ & $0.30575(7)$ & $0.23567(10)$ & $0.0237(2)$ \\
\hline $\mathrm{C} 8$ & $0.22305(13)$ & $0.30312(7)$ & $0.33731(10)$ & $0.0223(2)$ \\
\hline C9 & $0.20587(14)$ & $0.37330(7)$ & $0.38765(10)$ & $0.0241(2)$ \\
\hline H9 & $0.2472(18)$ & $0.4183(10)$ & $0.3553(13)$ & $0.031(4)^{*}$ \\
\hline $\mathrm{C} 10$ & $0.13615(13)$ & $0.38965(7)$ & $0.48567(10)$ & $0.0232(2)$ \\
\hline C11 & $0.18203(13)$ & $0.45583(7)$ & $0.55067(10)$ & $0.0239(2)$ \\
\hline $\mathrm{C} 12$ & $0.11763(15)$ & $0.47512(8)$ & $0.64272(11)$ & $0.0266(3)$ \\
\hline H12 & $0.152(2)$ & $0.5194(11)$ & $0.6845(14)$ & $0.040(5)^{*}$ \\
\hline $\mathrm{C} 13$ & $0.00202(14)$ & $0.42783(8)$ & $0.67128(10)$ & $0.0261(3)$ \\
\hline $\mathrm{C} 14$ & $-0.04785(15)$ & $0.36229(8)$ & $0.61082(11)$ & $0.0283(3)$ \\
\hline H14 & $-0.130(2)$ & $0.3302(11)$ & $0.6306(14)$ & $0.038(4)^{*}$ \\
\hline $\mathrm{C} 15$ & $0.01925(15)$ & $0.34384(8)$ & $0.51908(11)$ & $0.0271(3)$ \\
\hline H15 & $-0.019(2)$ & $0.3021(11)$ & $0.4758(15)$ & $0.042(5)^{*}$ \\
\hline C16 & $0.43514(15)$ & $0.24544(8)$ & $0.10287(10)$ & $0.0261(3)$ \\
\hline H16A & $0.4342(18)$ & $0.1915(10)$ & $0.0694(13)$ & $0.029(4)^{*}$ \\
\hline H16B & $0.3717(18)$ & $0.2771(10)$ & $0.0550(13)$ & $0.027(4)^{*}$ \\
\hline
\end{tabular}
on $\mathrm{F}^{2}$ are statistically about twice as large as those based on F, and R- factors based on ALL data will be even larger.

Fractional atomic coordinates and isotropic or equivalent isotropic displacement parameters $\left(\AA^{2}\right)$ 


\begin{tabular}{lllll} 
C17 & $0.59004(14)$ & $0.28115(7)$ & $0.11411(10)$ & $0.0235(2)$ \\
C18 & $0.65243(16)$ & $0.30239(9)$ & $0.02058(11)$ & $0.0311(3)$ \\
H18 & $0.593(2)$ & $0.2943(11)$ & $-0.0487(15)$ & $0.039(5)^{*}$ \\
C19 & $0.79411(17)$ & $0.33523(9)$ & $0.02566(13)$ & $0.0384(3)$ \\
H19 & $0.835(2)$ & $0.3503(12)$ & $-0.0383(16)$ & $0.050(5)^{*}$ \\
C20 & $0.87604(17)$ & $0.34739(9)$ & $0.12401(14)$ & $0.0382(3)$ \\
H20 & $0.973(2)$ & $0.3695(12)$ & $0.1271(15)$ & $0.046(5)^{*}$ \\
C21 & $0.81497(16)$ & $0.32701(8)$ & $0.21707(13)$ & $0.0334(3)$ \\
H21 & $0.874(2)$ & $0.3354(11)$ & $0.2875(14)$ & $0.040(5)^{*}$ \\
C22 & $0.67257(15)$ & $0.29448(8)$ & $0.21258(11)$ & $0.0273(3)$ \\
H22 & $0.6283(17)$ & $0.2799(9)$ & $0.2793(12)$ & $0.024(4)^{*}$ \\
\hline
\end{tabular}

Atomic displacement parameters $\left(\AA^{2}\right)$

\begin{tabular}{lllllll}
\hline & $U^{11}$ & $U^{22}$ & $U^{33}$ & $U^{12}$ & $U^{13}$ & $U^{23}$ \\
\hline C11 & $0.02604(16)$ & $0.03290(17)$ & $0.04160(19)$ & $-0.00735(12)$ & $0.00829(13)$ & $-0.00211(13)$ \\
C12 & $0.03839(18)$ & $0.03495(18)$ & $0.03231(17)$ & $0.00967(13)$ & $0.01489(13)$ & $0.00164(12)$ \\
S1 & $0.02266(15)$ & $0.02109(15)$ & $0.03075(17)$ & $-0.00207(11)$ & $0.00738(12)$ & $0.00098(11)$ \\
O1 & $0.0405(5)$ & $0.0264(5)$ & $0.0303(5)$ & $0.0018(4)$ & $0.0116(4)$ & $0.0066(4)$ \\
N1 & $0.0226(5)$ & $0.0248(5)$ & $0.0224(5)$ & $-0.0006(4)$ & $0.0050(4)$ & $0.0000(4)$ \\
C1 & $0.0225(6)$ & $0.0217(6)$ & $0.0261(6)$ & $-0.0018(5)$ & $0.0009(5)$ & $-0.0017(5)$ \\
C2 & $0.0297(7)$ & $0.0241(6)$ & $0.0321(7)$ & $-0.0029(5)$ & $0.0017(5)$ & $0.0022(5)$ \\
C3 & $0.0349(7)$ & $0.0215(6)$ & $0.0406(8)$ & $0.0005(5)$ & $-0.0015(6)$ & $0.0025(5)$ \\
C4 & $0.0295(7)$ & $0.0245(6)$ & $0.0446(8)$ & $0.0037(5)$ & $0.0022(6)$ & $-0.0047(6)$ \\
C5 & $0.0253(6)$ & $0.0267(6)$ & $0.0337(7)$ & $-0.0007(5)$ & $0.0044(5)$ & $-0.0047(5)$ \\
C6 & $0.0225(6)$ & $0.0214(6)$ & $0.0255(6)$ & $-0.0026(5)$ & $0.0004(5)$ & $-0.0020(5)$ \\
C7 & $0.0223(6)$ & $0.0241(6)$ & $0.0247(6)$ & $-0.0015(5)$ & $0.0025(5)$ & $0.0010(5)$ \\
C8 & $0.0194(5)$ & $0.0231(6)$ & $0.0246(6)$ & $0.0002(4)$ & $0.0034(4)$ & $0.0033(4)$ \\
C9 & $0.0229(6)$ & $0.0224(6)$ & $0.0276(6)$ & $0.0000(5)$ & $0.0051(5)$ & $0.0036(5)$ \\
C10 & $0.0228(6)$ & $0.0207(6)$ & $0.0265(6)$ & $0.0038(5)$ & $0.0041(5)$ & $0.0034(4)$ \\
C11 & $0.0201(6)$ & $0.0224(6)$ & $0.0293(6)$ & $0.0025(4)$ & $0.0034(5)$ & $0.0033(5)$ \\
C12 & $0.0259(6)$ & $0.0242(6)$ & $0.0293(6)$ & $0.0039(5)$ & $0.0015(5)$ & $-0.0006(5)$ \\
C13 & $0.0265(6)$ & $0.0260(6)$ & $0.0267(6)$ & $0.0083(5)$ & $0.0069(5)$ & $0.0042(5)$ \\
C14 & $0.0279(6)$ & $0.0238(6)$ & $0.0350(7)$ & $0.0014(5)$ & $0.0111(5)$ & $0.0048(5)$ \\
C15 & $0.0281(6)$ & $0.0222(6)$ & $0.0318(7)$ & $-0.0001(5)$ & $0.0075(5)$ & $0.0002(5)$ \\
C16 & $0.0273(6)$ & $0.0315(7)$ & $0.0196(6)$ & $-0.0010(5)$ & $0.0033(5)$ & $-0.0020(5)$ \\
C17 & $0.0256(6)$ & $0.0215(6)$ & $0.0240(6)$ & $0.0032(5)$ & $0.0062(5)$ & $0.0002(4)$ \\
C18 & $0.0344(7)$ & $0.0333(7)$ & $0.0271(7)$ & $0.0065(6)$ & $0.0104(5)$ & $0.0039(5)$ \\
C19 & $0.0385(8)$ & $0.0330(7)$ & $0.0476(9)$ & $0.0061(6)$ & $0.0232(7)$ & $0.0101(6)$ \\
C20 & $0.0270(7)$ & $0.0262(7)$ & $0.0630(10)$ & $-0.0002(5)$ & $0.0123(6)$ & $0.0026(6)$ \\
C21 & $0.0290(7)$ & $0.0262(7)$ & $0.0442(8)$ & $-0.0002(5)$ & $-0.0002(6)$ & $-0.0042(6)$ \\
C22 & $0.0294(6)$ & $0.0261(6)$ & $0.0265(6)$ & $-0.0009(5)$ & $0.0042(5)$ & $-0.0013(5)$ \\
& & & & & & \\
\hline & & & & & &
\end{tabular}

Geometric parameters $\left(\AA,{ }^{\circ}\right)$

\begin{tabular}{llll}
\hline $\mathrm{C} 11-\mathrm{C} 11$ & $1.7357(13)$ & $\mathrm{C} 10-\mathrm{C} 11$ & $1.4076(18)$ \\
$\mathrm{C} 12-\mathrm{C} 13$ & $1.7382(13)$ & $\mathrm{C} 11-\mathrm{C} 12$ & $1.3814(18)$ \\
$\mathrm{S} 1-\mathrm{C} 8$ & $1.7525(12)$ & $\mathrm{C} 12-\mathrm{C} 13$ & $1.3854(19)$
\end{tabular}




\begin{tabular}{|c|c|c|c|}
\hline $\mathrm{S} 1-\mathrm{C} 1$ & $1.7561(13)$ & $\mathrm{C} 12-\mathrm{H} 12$ & 0.940 (19) \\
\hline $\mathrm{O} 1-\mathrm{C} 7$ & $1.2228(16)$ & $\mathrm{C} 13-\mathrm{C} 14$ & $1.3781(19)$ \\
\hline $\mathrm{N} 1-\mathrm{C} 7$ & $1.3759(16)$ & $\mathrm{C} 14-\mathrm{C} 15$ & $1.3874(19)$ \\
\hline N1-C6 & $1.4192(16)$ & $\mathrm{C} 14-\mathrm{H} 14$ & $0.971(19)$ \\
\hline N1-C16 & $1.4661(16)$ & $\mathrm{C} 15-\mathrm{H} 15$ & 0.928 (19) \\
\hline $\mathrm{C} 1-\mathrm{C} 2$ & $1.3967(18)$ & $\mathrm{C} 16-\mathrm{C} 17$ & $1.5143(18)$ \\
\hline $\mathrm{C} 1-\mathrm{C} 6$ & $1.4000(18)$ & $\mathrm{C} 16-\mathrm{H} 16 \mathrm{~A}$ & $0.993(17)$ \\
\hline $\mathrm{C} 2-\mathrm{C} 3$ & $1.387(2)$ & $\mathrm{C} 16-\mathrm{H} 16 \mathrm{~B}$ & 0.945 (16) \\
\hline $\mathrm{C} 2-\mathrm{H} 2$ & $0.981(18)$ & $\mathrm{C} 17-\mathrm{C} 22$ & $1.3899(18)$ \\
\hline $\mathrm{C} 3-\mathrm{C} 4$ & 1.387 (2) & $\mathrm{C} 17-\mathrm{C} 18$ & $1.3965(18)$ \\
\hline $\mathrm{C} 3-\mathrm{H} 3$ & 0.938 (17) & $\mathrm{C} 18-\mathrm{C} 19$ & $1.388(2)$ \\
\hline $\mathrm{C} 4-\mathrm{C} 5$ & $1.388(2)$ & $\mathrm{C} 18-\mathrm{H} 18$ & 0.979 (18) \\
\hline $\mathrm{C} 4-\mathrm{H} 4$ & $0.94(2)$ & $\mathrm{C} 19-\mathrm{C} 20$ & $1.383(2)$ \\
\hline $\mathrm{C} 5-\mathrm{C} 6$ & $1.3990(18)$ & C19-H19 & $0.95(2)$ \\
\hline $\mathrm{C} 5-\mathrm{H} 5$ & $0.960(18)$ & $\mathrm{C} 20-\mathrm{C} 21$ & $1.382(2)$ \\
\hline $\mathrm{C} 7-\mathrm{C} 8$ & $1.4988(17)$ & $\mathrm{C} 20-\mathrm{H} 20$ & $0.95(2)$ \\
\hline $\mathrm{C} 8-\mathrm{C} 9$ & $1.3458(18)$ & $\mathrm{C} 21-\mathrm{C} 22$ & $1.392(2)$ \\
\hline $\mathrm{C} 9-\mathrm{C} 10$ & $1.4616(17)$ & $\mathrm{C} 21-\mathrm{H} 21$ & $0.993(18)$ \\
\hline C9-H9 & $0.948(17)$ & $\mathrm{C} 22-\mathrm{H} 22$ & $0.992(16)$ \\
\hline $\mathrm{C} 10-\mathrm{C} 15$ & $1.4024(18)$ & & \\
\hline $\mathrm{C} 11 \cdots \mathrm{Cl}^{\mathrm{i}}$ & $3.2439(5)$ & C6 $\cdots$ C 22 & $3.4830(18)$ \\
\hline $\mathrm{Cl1} \cdots \mathrm{C} 14^{\mathrm{ii}}$ & $3.4981(14)$ & C6 $\cdots \mathrm{C} 12^{\mathrm{v}}$ & $3.5828(18)$ \\
\hline $\mathrm{Cl} 1 \cdots \mathrm{H} 9$ & $2.647(16)$ & $\mathrm{C} 7 \cdots \mathrm{C} 22$ & $3.4391(18)$ \\
\hline $\mathrm{Cl} 2 \cdots \mathrm{H} 19^{\mathrm{iii}}$ & $2.96(2)$ & $\mathrm{C} 10 \cdots \mathrm{C} 12^{\mathrm{ii}}$ & $3.4871(18)$ \\
\hline $\mathrm{Cl} 2 \cdots \mathrm{H} 9^{\mathrm{ii}}$ & 3.044 (16) & $\mathrm{C} 14 \cdots \mathrm{C} 20^{\mathrm{iv}}$ & $3.572(2)$ \\
\hline $\mathrm{Cl} 2 \cdots \mathrm{H} 4^{\mathrm{iv}}$ & 3.138 (18) & $\mathrm{C} 5 \cdots \mathrm{H} 16 \mathrm{~A}$ & $2.563(16)$ \\
\hline $\mathrm{S} 1 \cdots \mathrm{Cl} 2^{\mathrm{v}}$ & $3.5832(5)$ & $\mathrm{C} 6 \cdots \mathrm{H} 22$ & $2.904(15)$ \\
\hline $\mathrm{S} 1 \cdots \mathrm{Cl} 2^{\mathrm{v}}$ & $3.5832(5)$ & $\mathrm{C} 8 \cdots \mathrm{H} 15$ & $2.929(18)$ \\
\hline $\mathrm{S} 1 \cdots \mathrm{N} 1$ & $3.0801(11)$ & $\mathrm{C} 16 \cdots \mathrm{H} 5$ & $2.556(18)$ \\
\hline $\mathrm{S} 1 \cdots \mathrm{C} 15$ & 3.1625 (14) & $\mathrm{C} 17 \cdots \mathrm{H} 5$ & $2.829(18)$ \\
\hline $\mathrm{S} 1 \cdots \mathrm{C} 13^{\mathrm{v}}$ & $3.6033(13)$ & $\mathrm{C} 18 \cdots \mathrm{H} 3^{\text {vi }}$ & $2.998(17)$ \\
\hline $\mathrm{S} 1 \cdots \mathrm{H} 15$ & $2.578(18)$ & $\mathrm{C} 21 \cdots \mathrm{H} 12^{\mathrm{i}}$ & $2.845(18)$ \\
\hline $\mathrm{O} 1 \cdots \mathrm{C} 17$ & $3.2096(16)$ & $\mathrm{H} 14 \cdots \mathrm{C} 20^{\mathrm{iv}}$ & $2.964(18)$ \\
\hline $\mathrm{O} 1 \cdots \mathrm{C}^{\mathrm{vi}}$ & $3.3346(17)$ & $\mathrm{H} 14 \cdots \mathrm{C} 21^{\mathrm{iv}}$ & $2.899(18)$ \\
\hline $\mathrm{O} 1 \cdots \mathrm{H} 9$ & $2.406(16)$ & $\mathrm{H} 14 \cdots \mathrm{C} 22^{\mathrm{iv}}$ & $2.990(18)$ \\
\hline $\mathrm{O} 1 \cdots \mathrm{H} 16 \mathrm{~B}$ & $2.345(16)$ & $\mathrm{H} 15 \cdots \mathrm{C} 19^{\text {iv }}$ & $2.951(18)$ \\
\hline $\mathrm{O} 1 \cdots \mathrm{H} 4^{\mathrm{vi}}$ & $2.51(2)$ & $\mathrm{H} 16 \mathrm{~B} \cdots \mathrm{S} 1^{\mathrm{v}}$ & $2.852(16)$ \\
\hline $\mathrm{N} 1 \cdots \mathrm{S} 1$ & $3.0801(11)$ & $\mathrm{H} 16 \mathrm{~B} \cdots \mathrm{C} 1^{\mathrm{v}}$ & $2.973(16)$ \\
\hline $\mathrm{N} 1 \cdots \mathrm{H} 22$ & $2.552(15)$ & $\mathrm{H} 18 \cdots \mathrm{C} 6^{\mathrm{v}}$ & 2.934 (19) \\
\hline $\mathrm{C} 1 \cdots \mathrm{C} 12^{\mathrm{v}}$ & $3.4639(18)$ & $\mathrm{H} 5 \cdots \mathrm{H} 16 \mathrm{~A}$ & $2.16(2)$ \\
\hline $\mathrm{C} 1 \cdots \mathrm{C} 13^{\mathrm{v}}$ & $3.4372(18)$ & $\mathrm{H} 12 \cdots \mathrm{H} 21^{\mathrm{i}}$ & $2.46(3)$ \\
\hline $\mathrm{C} 2 \cdots \mathrm{C} 12^{\mathrm{v}}$ & $3.541(2)$ & $\mathrm{H} 15 \cdots \mathrm{H} 21^{\text {viii }}$ & $2.51(3)$ \\
\hline $\mathrm{C} 3 \cdots \mathrm{C} 3^{\text {vii }}$ & $3.485(2)$ & H16B $\cdots \mathrm{H} 18$ & $2.51(2)$ \\
\hline $\mathrm{C} 5 \cdots \mathrm{C} 22$ & $3.4988(19)$ & $\mathrm{H} 18 \cdots \mathrm{H} 22^{\mathrm{v}}$ & $2.53(2)$ \\
\hline $\mathrm{C} 5 \cdots \mathrm{C} 17$ & $3.4201(18)$ & & \\
\hline $\mathrm{C} 8-\mathrm{S} 1-\mathrm{C} 1$ & $100.14(6)$ & $\mathrm{C} 11-\mathrm{C} 12-\mathrm{C} 13$ & $118.49(12)$ \\
\hline
\end{tabular}




\begin{tabular}{|c|c|c|c|}
\hline $\mathrm{C} 7-\mathrm{N} 1-\mathrm{C} 6$ & $125.51(10)$ & $\mathrm{C} 11-\mathrm{C} 12-\mathrm{H} 12$ & $120.1(11)$ \\
\hline $\mathrm{C} 7-\mathrm{N} 1-\mathrm{C} 16$ & $115.14(10)$ & $\mathrm{C} 13-\mathrm{C} 12-\mathrm{H} 12$ & $121.4(11)$ \\
\hline $\mathrm{C} 6-\mathrm{N} 1-\mathrm{C} 16$ & $119.20(10)$ & $\mathrm{C} 14-\mathrm{C} 13-\mathrm{C} 12$ & $121.49(12)$ \\
\hline $\mathrm{C} 2-\mathrm{C} 1-\mathrm{C} 6$ & $120.71(12)$ & $\mathrm{C} 14-\mathrm{C} 13-\mathrm{Cl} 2$ & $119.70(10)$ \\
\hline $\mathrm{C} 2-\mathrm{C} 1-\mathrm{S} 1$ & $117.26(10)$ & $\mathrm{C} 12-\mathrm{C} 13-\mathrm{Cl} 2$ & $118.79(10)$ \\
\hline $\mathrm{C} 6-\mathrm{C} 1-\mathrm{S} 1$ & $122.02(10)$ & $\mathrm{C} 13-\mathrm{C} 14-\mathrm{C} 15$ & $118.94(12)$ \\
\hline $\mathrm{C} 3-\mathrm{C} 2-\mathrm{C} 1$ & $120.17(13)$ & $\mathrm{C} 13-\mathrm{C} 14-\mathrm{H} 14$ & $120.9(10)$ \\
\hline $\mathrm{C} 3-\mathrm{C} 2-\mathrm{H} 2$ & $121.4(10)$ & $\mathrm{C} 15-\mathrm{C} 14-\mathrm{H} 14$ & $120.1(10)$ \\
\hline $\mathrm{C} 1-\mathrm{C} 2-\mathrm{H} 2$ & $118.5(10)$ & $\mathrm{C} 14-\mathrm{C} 15-\mathrm{C} 10$ & $122.24(12)$ \\
\hline $\mathrm{C} 4-\mathrm{C} 3-\mathrm{C} 2$ & $119.47(13)$ & $\mathrm{C} 14-\mathrm{C} 15-\mathrm{H} 15$ & $118.7(12)$ \\
\hline $\mathrm{C} 4-\mathrm{C} 3-\mathrm{H} 3$ & $120.7(10)$ & $\mathrm{C} 10-\mathrm{C} 15-\mathrm{H} 15$ & $118.9(12)$ \\
\hline $\mathrm{C} 2-\mathrm{C} 3-\mathrm{H} 3$ & $119.8(10)$ & $\mathrm{N} 1-\mathrm{C} 16-\mathrm{C} 17$ & $115.04(10)$ \\
\hline $\mathrm{C} 3-\mathrm{C} 4-\mathrm{C} 5$ & $120.59(13)$ & $\mathrm{N} 1-\mathrm{C} 16-\mathrm{H} 16 \mathrm{~A}$ & $107.3(9)$ \\
\hline $\mathrm{C} 3-\mathrm{C} 4-\mathrm{H} 4$ & $119.6(12)$ & $\mathrm{C} 17-\mathrm{C} 16-\mathrm{H} 16 \mathrm{~A}$ & $111.3(9)$ \\
\hline $\mathrm{C} 5-\mathrm{C} 4-\mathrm{H} 4$ & $119.7(12)$ & $\mathrm{N} 1-\mathrm{C} 16-\mathrm{H} 16 \mathrm{~B}$ & $108.1(10)$ \\
\hline $\mathrm{C} 4-\mathrm{C} 5-\mathrm{C} 6$ & $120.71(13)$ & $\mathrm{C} 17-\mathrm{C} 16-\mathrm{H} 16 \mathrm{~B}$ & $109.4(10)$ \\
\hline $\mathrm{C} 4-\mathrm{C} 5-\mathrm{H} 5$ & $118.7(10)$ & $\mathrm{H} 16 \mathrm{~A}-\mathrm{C} 16-\mathrm{H} 16 \mathrm{~B}$ & $105.2(13)$ \\
\hline $\mathrm{C} 6-\mathrm{C} 5-\mathrm{H} 5$ & $120.6(11)$ & $\mathrm{C} 22-\mathrm{C} 17-\mathrm{C} 18$ & $118.42(12)$ \\
\hline $\mathrm{C} 5-\mathrm{C} 6-\mathrm{C} 1$ & $118.24(12)$ & $\mathrm{C} 22-\mathrm{C} 17-\mathrm{C} 16$ & $123.41(11)$ \\
\hline $\mathrm{C} 5-\mathrm{C} 6-\mathrm{N} 1$ & $120.50(11)$ & $\mathrm{C} 18-\mathrm{C} 17-\mathrm{C} 16$ & $118.16(12)$ \\
\hline $\mathrm{C} 1-\mathrm{C} 6-\mathrm{N} 1$ & $121.26(11)$ & $\mathrm{C} 19-\mathrm{C} 18-\mathrm{C} 17$ & $120.85(14)$ \\
\hline $\mathrm{O} 1-\mathrm{C} 7-\mathrm{N} 1$ & $120.68(11)$ & $\mathrm{C} 19-\mathrm{C} 18-\mathrm{H} 18$ & $120.7(11)$ \\
\hline $\mathrm{O} 1-\mathrm{C} 7-\mathrm{C} 8$ & $120.54(11)$ & $\mathrm{C} 17-\mathrm{C} 18-\mathrm{H} 18$ & $118.5(11)$ \\
\hline $\mathrm{N} 1-\mathrm{C} 7-\mathrm{C} 8$ & $118.78(10)$ & $\mathrm{C} 20-\mathrm{C} 19-\mathrm{C} 18$ & $120.29(14)$ \\
\hline $\mathrm{C} 9-\mathrm{C} 8-\mathrm{C} 7$ & $117.09(11)$ & $\mathrm{C} 20-\mathrm{C} 19-\mathrm{H} 19$ & $119.3(12)$ \\
\hline $\mathrm{C} 9-\mathrm{C} 8-\mathrm{S} 1$ & $124.79(10)$ & $\mathrm{C} 18-\mathrm{C} 19-\mathrm{H} 19$ & $120.4(12)$ \\
\hline $\mathrm{C} 7-\mathrm{C} 8-\mathrm{S} 1$ & $117.88(9)$ & $\mathrm{C} 21-\mathrm{C} 20-\mathrm{C} 19$ & $119.32(14)$ \\
\hline $\mathrm{C} 8-\mathrm{C} 9-\mathrm{C} 10$ & $129.48(12)$ & $\mathrm{C} 21-\mathrm{C} 20-\mathrm{H} 20$ & $120.6(11)$ \\
\hline $\mathrm{C} 8-\mathrm{C} 9-\mathrm{H} 9$ & $114.8(10)$ & $\mathrm{C} 19-\mathrm{C} 20-\mathrm{H} 20$ & $120.1(11)$ \\
\hline $\mathrm{C} 10-\mathrm{C} 9-\mathrm{H} 9$ & $115.7(10)$ & $\mathrm{C} 20-\mathrm{C} 21-\mathrm{C} 22$ & $120.69(14)$ \\
\hline $\mathrm{C} 15-\mathrm{C} 10-\mathrm{C} 11$ & $116.15(11)$ & $\mathrm{C} 20-\mathrm{C} 21-\mathrm{H} 21$ & $119.2(11)$ \\
\hline $\mathrm{C} 15-\mathrm{C} 10-\mathrm{C} 9$ & $123.53(12)$ & $\mathrm{C} 22-\mathrm{C} 21-\mathrm{H} 21$ & $120.1(11)$ \\
\hline $\mathrm{C} 11-\mathrm{C} 10-\mathrm{C} 9$ & $120.29(11)$ & $\mathrm{C} 17-\mathrm{C} 22-\mathrm{C} 21$ & $120.43(13)$ \\
\hline $\mathrm{C} 12-\mathrm{C} 11-\mathrm{C} 10$ & $122.68(12)$ & $\mathrm{C} 17-\mathrm{C} 22-\mathrm{H} 22$ & $118.7(9)$ \\
\hline $\mathrm{C} 12-\mathrm{C} 11-\mathrm{C} 11$ & $117.23(10)$ & $\mathrm{C} 21-\mathrm{C} 22-\mathrm{H} 22$ & $120.9(9)$ \\
\hline $\mathrm{C} 10-\mathrm{C} 11-\mathrm{C} 11$ & $120.08(10)$ & & \\
\hline $\mathrm{C} 8-\mathrm{S} 1-\mathrm{C} 1-\mathrm{C} 2$ & $155.71(10)$ & $\mathrm{S} 1-\mathrm{C} 8-\mathrm{C} 9-\mathrm{C} 10$ & $4.6(2)$ \\
\hline $\mathrm{C} 8-\mathrm{S} 1-\mathrm{C} 1-\mathrm{C} 6$ & $-25.73(11)$ & $\mathrm{C} 8-\mathrm{C} 9-\mathrm{C} 10-\mathrm{C} 15$ & $-29.8(2)$ \\
\hline $\mathrm{C} 6-\mathrm{C} 1-\mathrm{C} 2-\mathrm{C} 3$ & $-1.12(19)$ & $\mathrm{C} 8-\mathrm{C} 9-\mathrm{C} 10-\mathrm{C} 11$ & $152.34(13)$ \\
\hline $\mathrm{S} 1-\mathrm{C} 1-\mathrm{C} 2-\mathrm{C} 3$ & $177.47(10)$ & $\mathrm{C} 15-\mathrm{C} 10-\mathrm{C} 11-\mathrm{C} 12$ & $0.42(18)$ \\
\hline $\mathrm{C} 1-\mathrm{C} 2-\mathrm{C} 3-\mathrm{C} 4$ & $3.0(2)$ & $\mathrm{C} 9-\mathrm{C} 10-\mathrm{C} 11-\mathrm{C} 12$ & $178.46(11)$ \\
\hline $\mathrm{C} 2-\mathrm{C} 3-\mathrm{C} 4-\mathrm{C} 5$ & $-1.7(2)$ & $\mathrm{C} 15-\mathrm{C} 10-\mathrm{C} 11-\mathrm{C} 11$ & $179.25(9)$ \\
\hline $\mathrm{C} 3-\mathrm{C} 4-\mathrm{C} 5-\mathrm{C} 6$ & $-1.5(2)$ & $\mathrm{C} 9-\mathrm{C} 10-\mathrm{C} 11-\mathrm{Cl} 1$ & $-2.71(16)$ \\
\hline $\mathrm{C} 4-\mathrm{C} 5-\mathrm{C} 6-\mathrm{C} 1$ & $3.35(19)$ & $\mathrm{C} 10-\mathrm{C} 11-\mathrm{C} 12-\mathrm{C} 13$ & $-0.78(19)$ \\
\hline $\mathrm{C} 4-\mathrm{C} 5-\mathrm{C} 6-\mathrm{N} 1$ & $-175.72(12)$ & $\mathrm{C} 11-\mathrm{C} 11-\mathrm{C} 12-\mathrm{C} 13$ & $-179.64(9)$ \\
\hline $\mathrm{C} 2-\mathrm{C} 1-\mathrm{C} 6-\mathrm{C} 5$ & $-2.05(18)$ & $\mathrm{C} 11-\mathrm{C} 12-\mathrm{C} 13-\mathrm{C} 14$ & $0.72(19)$ \\
\hline $\mathrm{S} 1-\mathrm{C} 1-\mathrm{C} 6-\mathrm{C} 5$ & $179.43(9)$ & $\mathrm{C} 11-\mathrm{C} 12-\mathrm{C} 13-\mathrm{Cl} 2$ & $-177.88(9)$ \\
\hline
\end{tabular}




\begin{tabular}{llll}
$\mathrm{C} 2-\mathrm{C} 1-\mathrm{C} 6-\mathrm{N} 1$ & $177.02(11)$ & $\mathrm{C} 12-\mathrm{C} 13-\mathrm{C} 14-\mathrm{C} 15$ & $-0.33(19)$ \\
$\mathrm{S} 1-\mathrm{C} 1-\mathrm{C} 6-\mathrm{N} 1$ & $-1.50(17)$ & $\mathrm{C} 12-\mathrm{C} 13-\mathrm{C} 14-\mathrm{C} 15$ & $178.27(10)$ \\
$\mathrm{C} 7-\mathrm{N} 1-\mathrm{C} 6-\mathrm{C} 5$ & $-158.93(12)$ & $\mathrm{C} 13-\mathrm{C} 14-\mathrm{C} 15-\mathrm{C} 10$ & $0.0(2)$ \\
$\mathrm{C} 16-\mathrm{N} 1-\mathrm{C} 6-\mathrm{C} 5$ & $16.29(17)$ & $\mathrm{C} 11-\mathrm{C} 10-\mathrm{C} 15-\mathrm{C} 14$ & $0.00(19)$ \\
$\mathrm{C} 7-\mathrm{N} 1-\mathrm{C} 6-\mathrm{C} 1$ & $22.03(18)$ & $\mathrm{C} 9-\mathrm{C} 10-\mathrm{C} 15-\mathrm{C} 14$ & $-177.97(12)$ \\
$\mathrm{C} 16-\mathrm{N} 1-\mathrm{C} 6-\mathrm{C} 1$ & $-162.76(11)$ & $\mathrm{C} 7-\mathrm{N} 1-\mathrm{C} 16-\mathrm{C} 17$ & $84.01(14)$ \\
$\mathrm{C} 6-\mathrm{N} 1-\mathrm{C} 7-\mathrm{O} 1$ & $174.42(12)$ & $\mathrm{C} 6-\mathrm{N} 1-\mathrm{C} 16-\mathrm{C} 17$ & $-91.69(14)$ \\
$\mathrm{C} 16-\mathrm{N} 1-\mathrm{C} 7-\mathrm{O} 1$ & $-0.96(17)$ & $\mathrm{N} 1-\mathrm{C} 16-\mathrm{C} 17-\mathrm{C} 22$ & $9.68(18)$ \\
$\mathrm{C} 6-\mathrm{N} 1-\mathrm{C} 7-\mathrm{C} 8$ & $-5.15(18)$ & $\mathrm{N} 1-\mathrm{C} 16-\mathrm{C} 17-\mathrm{C} 18$ & $-169.73(11)$ \\
$\mathrm{C} 16-\mathrm{N} 1-\mathrm{C} 7-\mathrm{C} 8$ & $179.46(10)$ & $\mathrm{C} 22-\mathrm{C} 17-\mathrm{C} 18-\mathrm{C} 19$ & $0.7(2)$ \\
$\mathrm{O} 1-\mathrm{C} 7-\mathrm{C} 8-\mathrm{C} 9$ & $-23.67(18)$ & $\mathrm{C} 16-\mathrm{C} 17-\mathrm{C} 18-\mathrm{C} 19$ & $-179.87(13)$ \\
$\mathrm{N} 1-\mathrm{C} 7-\mathrm{C} 8-\mathrm{C} 9$ & $155.91(11)$ & $\mathrm{C} 17-\mathrm{C} 18-\mathrm{C} 19-\mathrm{C} 20$ & $0.1(2)$ \\
$\mathrm{O} 1-\mathrm{C} 7-\mathrm{C} 8-\mathrm{S} 1$ & $150.91(10)$ & $\mathrm{C} 18-\mathrm{C} 19-\mathrm{C} 20-\mathrm{C} 21$ & $-0.4(2)$ \\
$\mathrm{N} 1-\mathrm{C} 7-\mathrm{C} 8-\mathrm{S} 1$ & $-29.52(15)$ & $\mathrm{C} 19-\mathrm{C} 20-\mathrm{C} 21-\mathrm{C} 22$ & $0.1(2)$ \\
$\mathrm{C} 1-\mathrm{S} 1-\mathrm{C} 8-\mathrm{C} 9$ & $-145.73(11)$ & $\mathrm{C} 18-\mathrm{C} 17-\mathrm{C} 22-\mathrm{C} 21$ & $-1.06(19)$ \\
$\mathrm{C} 1-\mathrm{S} 1-\mathrm{C} 8-\mathrm{C} 7$ & $40.15(10)$ & $\mathrm{C} 16-\mathrm{C} 17-\mathrm{C} 22-\mathrm{C} 21$ & $179.53(12)$ \\
$\mathrm{C} 7-\mathrm{C} 8-\mathrm{C} 9-\mathrm{C} 10$ & $178.71(12)$ & $\mathrm{C} 20-\mathrm{C} 21-\mathrm{C} 22-\mathrm{C} 17$ & $0.7(2)$ \\
\hline
\end{tabular}

Symmetry codes: (i) $-x+1,-y+1,-z+1$; (ii) $-x,-y+1,-z+1$; (iii) $x-1, y, z+1$; (iv) $x-1,-y+1 / 2, z+1 / 2$; (v) $x,-y+1 / 2, z-1 / 2$; (vi) $-x+1, y+1 / 2,-z+1 / 2$; (vii) $-x+1,-y,-z+1$; (viii) $x-1, y, z$.

Hydrogen-bond geometry $\left(A,{ }^{\circ}\right)$

\begin{tabular}{lllll}
\hline$D-\mathrm{H} \cdots A$ & $D-\mathrm{H}$ & $\mathrm{H} \cdots A$ & $D \cdots A$ & $D-\mathrm{H} \cdots A$ \\
\hline $\mathrm{C} 4-\mathrm{H} 4 \cdots \mathrm{O} 1^{\mathrm{ix}}$ & $0.936(19)$ & $2.51(2)$ & $3.3346(17)$ & $147.7(15)$ \\
$\mathrm{C} 16-\mathrm{H} 16 B \cdots \mathrm{S} 1^{\mathrm{v}}$ & $0.945(16)$ & $2.852(16)$ & $3.7011(13)$ & $149.9(12)$ \\
$\mathrm{C} 3-\mathrm{H} 3 \cdots C g 4^{\mathrm{ix}}$ & $0.938(17)$ & $2.901(17)$ & $3.6428(15)$ & $136.8(13)$ \\
$\mathrm{C} 14-\mathrm{H} 14 \cdots C g 4^{\mathrm{x}}$ & $0.971(19)$ & $2.710(18)$ & $3.5593(15)$ & $146.8(14)$ \\
$\mathrm{C} 18-\mathrm{H} 18 \cdots C g 1^{\mathrm{xi}}$ & $0.979(18)$ & $2.969(18)$ & $3.6759(16)$ & $130.0(13)$ \\
\hline
\end{tabular}

Symmetry codes: (v) $x,-y+1 / 2, z-1 / 2$; (ix) $-x+1, y-1 / 2,-z+1 / 2$; (x) $x-1,-y-1 / 2, z-1 / 2$; (xi) $x,-y-1 / 2, z-3 / 2$. 